\title{
Differential chemosensitization of P-glycoprotein overexpressing K562/Adr cells by withaferin A and Siamois polyphenols
}

\author{
Wipob Suttana1,3, Samlee Mankhetkorn', Wilart Poompimon², Ajay Palagani33, Sergey Zhokhov³, Sarah Gerlo3, \\ Guy Haegeman ${ }^{3}$ and Wim Vanden Berghe*3,4
}

\begin{abstract}
Background: Multidrug resistance (MDR) is a major obstacle in cancer treatment and is often the result of overexpression of the drug efflux protein, P-glycoprotein (P-gp), as a consequence of hyperactivation of NFKB, AP1 and Nrf2 transcription factors. In addition to effluxing chemotherapeutic drugs, P-gp also plays a specific role in blocking caspase-dependent apoptotic pathways. One feature that cytotoxic treatments of cancer have in common is activation of the transcription factor NFkB, which regulates inflammation, cell survival and P-gp expression and suppresses the apoptotic potential of chemotherapeutic agents. As such, NFkB inhibitors may promote apoptosis in cancer cells and could be used to overcome resistance to chemotherapeutic agents.

Results: Although the natural withanolide withaferin $A$ and polyphenol quercetin, show comparable inhibition of NFkB target genes (involved in inflammation, angiogenesis, cell cycle, metastasis, anti-apoptosis and multidrug resistance) in doxorubicin-sensitive K562 and -resistant K562/Adr cells, only withaferin A can overcome attenuated caspase activation and apoptosis in K562/Adr cells, whereas quercetin-dependent caspase activation and apoptosis is delayed only. Interestingly, although withaferin $A$ and quercetin treatments both decrease intracellular protein levels of $\mathrm{BCl} 2$, Bim and P-Bad, only withaferin A decreases protein levels of cytoskeletal tubulin, concomitantly with potent PARP cleavage, caspase 3 activation and apoptosis, at least in part via a direct thiol oxidation mechanism.
\end{abstract}

Conclusions: This demonstrates that different classes of natural NFkB inhibitors can show different chemosensitizing effects in P-gp overexpressing cancer cells with impaired caspase activation and attenuated apoptosis.

\section{Background}

The cytotoxicity of chemotherapeutic agents is attributed to apoptosis. One feature that cytotoxic treatments of cancer have in common is their activation of the transcription factor $\mathrm{NF}_{\mathrm{K} B}$, which regulates cell survival, suppresses the apoptotic potential of chemotherapeutic agents and contributes to drug resistance [1]. Acquired resistance to the effects of chemotherapy has emerged as a significant impediment to effective cancer therapy. As such, it is believed that inhibitors of NFKB might promote apoptosis in cancer cells and can be helpful to overcome resistance to chemotherapeutic agents.

\footnotetext{
* Correspondence: w.vandenberghe@ugent.be

${ }^{3}$ Laboratory of Eukaryotic Gene Expression and Signal Transduction (LEGEST), Department of Physiology, Ghent University, K.L.Ledeganckstraat 35, Gent, Belgium

Full list of author information is available at the end of the article
}

Nuclear factor kappa B (NFkB) is a family of transcription factors that play important roles in regulating cell differentiation, proliferation, immune response and blocking apoptosis $[2,3]$. In mammalian cells, the $\mathrm{NFkB} /$ Rel family consists of five members: RelA (p65), RelB, cRel, p105/p50 (NFkB1), and p100/p52 (NFkB2). Each family member has a conserved Rel homology domain specifying DNA binding, protein dimerization, and nuclear localization. In most cells, $\mathrm{NF} \kappa \mathrm{B}$ is composed of a heterodimer of p65 and p50, where the p65 protein is responsible for the transactivation potential. In unstimulated cells, NFkB is sequestered predominantly in the cytoplasm in an inactive complex through interaction with IKB inhibitor proteins. In response to stimulation by a variety of potent activators, such as tumor necrosis factor (TNF)- $\alpha$, interleukin (IL)-1, phorbol ester (PMA) or 
lipopolysaccharide [4] and genotoxic agents (doxorubicin, radiation) [5,6], IКB $\alpha$ is rapidly phosphorylated at two conserved $\mathrm{NH}_{2}$-terminal serines (Ser-32 and Ser-36) and degraded through a ubiquitin-dependent proteolysis, resulting in the release of $\mathrm{NFKB}$, its translocation into the nucleus and induction of gene transcription. The NFкB has a role in oncogenesis and regulation of cancer therapy sensitivity. Overexpression, amplification, and rearrangements of different genes related to NFkB have been observed in tumors [7]. NFkB is activated in response to various inflammatory stimuli including cytokines, mitogens, bacterial products, viral proteins, and apoptosisinducing agents $[8,9]$. Constitutive expression of $\mathrm{NF} \mathrm{KB}$ leads to activation of several factors involved in cell cycle progression and cell differentiation for cancer metastasis. Inhibition of NFKB activity in tumor cells dramatically reduces cell growth in vitro and in vivo [10]. NFKB, possibly through the activation of the antiapoptotic genes, plays a key role in the protection of cells against inducers of apoptosis including chemotherapeutic drugs [11]. Several mechanisms including increased expression of NFkB proteins, mutations and/or deletions in I $\mathrm{KB} \alpha$ gene, and

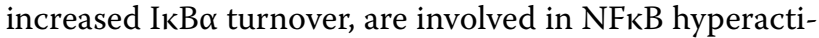
vation in tumor cells $[7,12]$. As such, various therapeutic strategies aim to decrease chronic $\mathrm{NF \kappa B}$ hyperactivation by pharmacological as well as phytomedicinal approaches in cancer [13-17]. NFkB-regulated genes are involved in cell death, invasiveness, proliferation, angiogenesis, inflammation and multidrug resistance (MDR). One of the most important mechanisms by which tumor cells resist to cytotoxic effects of a variety of chemotherapeutic drugs (including vinblastine, doxorubicine, etoposide and teniposide, as well as many other cytotoxic agents) is overexpression of the $m d r 1$ gene and its product, P-glycoprotein (P-gp) [18].

$\mathrm{P}$-gp is a $180 \mathrm{kDa}$ protein which belongs to the ATPbinding cassette $(A B C)$ superfamily of membrane transporter proteins $[19,20]$. It is expressed in various tissues, such as kidney tubules, colon, pancreas and adrenal gland, and tumors derived from these tissues are often resistant to chemotherapeutic drugs. Furthermore, $m d r 1$ expression is also increased in many relapsing cancers. Pgp is an energy-dependent drug efflux pump that maintains intracellular drug concentrations below cytotoxic levels, thereby decreasing the cytotoxic effects of a variety of chemotherapeutic agents, including anthracyclines, vinca alkaloids, and epipodophyllotoxins [18,21]. P-gp also plays a role in inhibition of drug accumulation and caspase activation in the MDR tumor [22-24]. Of special note, NFkB-mediated drug resistance was found to depend on the regulation of P-gp [25]. In addition, NFkBdependent regulation of P-gp expression has also been demonstrated in renal tubules or liver $[26,27]$. By upregu- lation of P-gp expression, NFKB was found to control drug efflux in cancer cells.

Cancer cells contain multiple signal transduction pathways whose activities are frequently increased due to cell transformation, and these pathways are often activated following cell exposure to established cytotoxic therapies, including ionizing radiation and chemical DNA-damaging agents. Many pathways activated in response to transformation or cytotoxic agents promote cell growth and invasion, which counteract the processes of cell death. As a result of these findings, many drugs with varying specificities have been developed to block the signaling by these cell survival pathways in the hope of killing tumor cells and sensitizing them to toxic therapies [28]. Unfortunately, due to the plasticity of signaling processes within a tumor cell, inhibition of a single growth factor receptor or signaling pathway frequently has only modest long-term effects on cancer cell viability, tumor growth, and patient survival. As a result of this observation, a greater emphasis has begun to be put on multi-target natural compounds, such as polyphenols, withanolides, xanthones, indanones, curcuminoids, which simultaneously inhibit multiple inter-linked signal transduction/survival pathways [14,28-33]. Hopefully, this could limit the ability of tumor cells to adapt and survive, because the activity within multiple parallel survival signaling pathways has been reduced [34]. As such, over the past decades, the efforts of researchers in looking for the new drugs to use in oncology have refocused on natural products $[1,34]$.

One of the expanding directions of modern medicine is based on using of natural phytochemical compounds. Polyphenols or phenolic compounds encompass molecules that possess an aromatic ring bearing one or more hydroxyl substituents. Natural polyphenols can range from simple molecules, such as phenolic acids and flavonoids, to large highly polymerized compounds, such as tannins [35]. This class of phytochemicals can be found in high concentrations in wide varieties of higher plants and their products, such as wine and tea. They were also demonstrated to exert a wide range of biological activities including antioxidant, anticarcinogenic, antiproliferative, antimicrobial anti-inflammatory and apoptosis-inducing activities [36-40].

Various polyphenols have been characterized with respect to their anti-invasive potential. Because invasion is, either directly or via metastasis formation, the main cause of death in cancer patients, development of efficient anti-invasive agents is an important research challenge [31]. Vanden Berghe et al. showed that phytoestrogenic soy isoflavones can selectively block nuclear $\mathrm{NFK}_{\mathrm{K}} \mathrm{B}$ transactivation of specific $\mathrm{NF}_{\mathrm{K}} \mathrm{B}$ target genes independently of their estrogenic activity in highly metastatic breast cancer cells [16]. In 12-O-tetradecanoylphorbol-13-acetate (TPA)-induced mouse skin 
tumor, the oligomeric and polymeric polyphenols decreased TPA-induced cell proliferation by attenuating the activation of signaling kinases [c-Jun N-terminal protein kinase (JNK), extracellular signal-regulated protein kinase-1/2 (ERK1/2), p38 protein kinase and Akt], transcription factors [activator protein-1 (AP1) and $\mathrm{NF}_{\kappa} \mathrm{B}$ ] and inflammatory protein [cyclooxygenase-2 (Cox-2)] $[41,42]$. The NFkB and Akt kinase pathways, which play critical roles in inflammation, vascular homeostasis and angiogenesis, were repressed by the polyphenolic compound deguelin in human vascular endothelial cells, HT1080 fibrosarcoma cells and chronic lymphocytic leukemia cells [43-45]. Nitric oxide production was reduced by the green tea polyphenols (-)-Epigallocatechin-3-gallate (EGCG) and black tea theaflavins by suppressing inducible nitric oxide synthase in a breast cancer cell line [46]. The latter treatment blocks nuclear translocation of the transcription factor NFkB as a result of decreased IкB kinase activity. However, anti-cancer effects of polyphenols may also indirectly also involve effects on immune cells at the cancer-inflammation interface. Several studies demonstrated that polyphenolic compounds exhibit antiinflammatory activity in activated macrophages by inhibiting the NFKB signaling pathway $[39,47,48]$. Dijsselbloem et al. demonstrated that genistein inhibits IL6 gene expression by modulating the transcription factor $\mathrm{NFK}_{\mathrm{B}}$ in TLR4-stimulated dendritic cells [49]. Pycnogenol inhibits $\mathrm{TNF} \alpha$-induced $\mathrm{NF}_{\kappa} \mathrm{B}$ activation and adhesion molecule expression in human vascular endothelial cells [50]. Red wine polyphenols, delphinidin and cyanidin inhibit platelet-derived growth factor ${ }_{\mathrm{AB}}\left(\mathrm{PDGF}_{\mathrm{AB}}\right)$ induced VEGF release in vascular smooth muscle cells by preventing activation of p38 MAPK and JNK [51]. Olive oil polyphenols exert rapid inhibition of p38 and CREB phosphorylation leading to a downstream reduction in COX-2 expression in human colonic adenocarcinoma, Caco-2 cells [52].

Previously, we have already reported the significant anti-cancer activities of quercetin, Siamois 1 and Siamois 2 polyphenols and the withasteroid withaferin A, which hold promise as dietary supplements in nutrition-based intervention in cancer treatment $[32,53]$. In this study we wanted to further investigate whether interference of Siamois polyphenols and withasteroids with NFkB-dependent apoptosis and inflammatory pathways can sensitize doxorubicin-resistant P-gp-overexpressing K562 erythroleukemic cells for cell death.

\section{Materials and methods Reagents and Chemicals}

Quercetin, Kaempferol, and Eriodictyol were from Extrasynthèse (Genay, France), Withaferin A from Chromadex (Irvine, US), whereas home-purified 5,3'-dihydroxy3,6,7,8,4'-pentamethoxyflavone (WP283) has been described elsewhere [54]. These compounds were stored as $100 \mathrm{mM}$ solutions in DMSO at $-20^{\circ} \mathrm{C}$. Doxorubicin hydrochloride was kindly provided by Dr. F. Offner (University Hospital UGent). Phorbol-12-myristate-13-acetate (PMA) was purchased from Sigma Chemical Company (St Louis, MO, USA) and stored as $1 \mathrm{mg} / \mathrm{ml}$ solution in DMSO at $-20^{\circ} \mathrm{C}$. Recombinant murine TNF, produced in Escherichia coli and purified in our laboratory to at least $99 \%$ homogeneity, had a specific biological activity of $8.58 \times 10^{7} \mathrm{IU} / \mathrm{ml}$ of protein as determined in a standard TNF cytolysis assay. Reference TNF (code 88/ 532) was obtained from the National Institute of Biological Standards and Control (Potters Bar, UK). Anti-IKB $\alpha$, anti-p65 (C20), anti-p50 (NLS), anti-cRel (N), anti-RelB (C19), anti-Fra1(H50), anti-Nrf2 (C10), anti-Bax antibodies were from Santa Cruz Biotechnology (Santa Cruz, CA), anti-p38, anti-p44/42, anti-cfos, anti-cjun, antijunB, anti-junD from Active Motif, anti-Sirt1 from Biomol, anti-Stat3 from Upstate, anti-histone-H3 antibodies from Abcam and anti-tubulin were from Sigma (Bornem, Belgium). The phospho-specific antibodies directed against p65 Ser536, p38 and p44/42 MAPK, cjun, Akt, MEK were from Cell Signaling (Beverly, CA). Anti-Bcl-2, anti-Bim, anti-Bad, anti-P-Bad antibodies were purchased from Cell Signaling (Boston, MA).

\section{Cell culture and Cytotoxicity assay}

Murine fibrosarcoma L929sA cells were maintained in Dulbecco's modified Eagle's medium supplemented with $5 \%$ newborn calf serum, $5 \%$ fetal calf serum, 100 units $/ \mathrm{ml}$ penicillin, and $0.1 \mathrm{mg} / \mathrm{ml}$ streptomycin. Twenty-four hours before induction, cells were seeded in multiwell dishes such that they were confluent at the time of the experiment.

Doxorubicin-sensitive erythroleukemic cells (K562) and doxorubicin-resistant erythroleukemic cells (K562/ Adr) which overexpress P-gp were grown in RPMI 1640 medium supplemented with $10 \%$ fetal calf serum, 100 units $/ \mathrm{ml}$ penicillin, and $0.1 \mathrm{mg} / \mathrm{ml}$ streptomycin, in an incubator at $37^{\circ} \mathrm{C}, 95 \%$ humidified, $5 \% \mathrm{CO}_{2}$. Cultures initiated at a density of $10^{5} \mathrm{cells} / \mathrm{ml}$ grew exponentially to about $10^{6}$ cells $/ \mathrm{ml}$ in 3 days. K562/Adr cell line was cultured in RPMI 1640 medium in the presence of $100 \mathrm{nM}$ doxorubicin for $72 \mathrm{~h}$, after that the cells were grown in RPMI 1640 medium without doxorubicin for 2 weeks before the experiments. For the assays and in order to have cells in the exponential growth phase, cultures were initiated at $5 \times 10^{5}$ cells $/ \mathrm{ml}$ and used $24 \mathrm{~h}$ later, reaching a density of about $8-10 \times 10^{5}$ cells $/ \mathrm{ml}$.

The cytotoxicity assay was performed as described previously [55]. Cells $\left(5 \times 10^{4}\right.$ cells $\left./ \mathrm{ml}\right)$ were incubated in the presence of various concentrations of compounds tested. The viability of cells was determined by MTT reduction. The concentration of compound required for $50 \%$ inhibi- 
tion of the proliferation of cells (IC50) was determined by plotting the percentage of cell growth inhibition (\%IC) versus the compound concentration when measured at $72 \mathrm{~h}$. Alternatively, cell cytotoxicity assays were performed by the ToxiLight Assay (Lonza) according to manufacturer's instructions.

\section{Apoptosis assay}

Cells were washed with ice-cold phosphate-buffered saline (PBS) after treatment, and $5 \times 10^{5}$ cells were stained with annexin $\mathrm{V}(\mathrm{AnnV})$-FITC during $15 \mathrm{~min}$ in the dark followed by propidium iodide (PI) staining (human AnnexinV-FITC Detection kit, Bender MedSystems Diagnostics, Vienna, Austria). The stained cells $\left(10^{4}\right.$ cells) were measured by flow cytometry (Cytomics FC500 1 laser, Beckman Coulter, Fullerton, USA) and results were expressed as percentage of living (AnnV-, PI-), early apoptotic (AnnV+, PI-), and late apoptotic/dead cells (AnnV+, PI+). The percent of living cells was normalized to $100 \%$ living cells incubated in control medium with $0.1 \%$ DMSO. All measurements were made in duplicate and averaged.

\section{IL6 ELISA}

IL6 cytokine levels in cell-free culture supernatants were determined using Hu-IL6 Cytoset ELISA kit (Biosource International Inc. Camarillo USA) with detection limits of $15 \mathrm{pg} / \mathrm{ml}$, according to the manufacturer's instructions. Three independent experiments were done, each in triplicate.

\section{Measurement of caspase- $3 / 7$ activity}

After appropriate induction, cells were washed with icecold PBS and the cytosolic cell lysate was prepared as described previously [56]. Measurement of caspase-3/7 activity was carried out by the incubation of cytosolic cell lysate with fluorogenic substrates, Ac-DEVD-AMC. The release of fluorescent AMC was monitored for $1 \mathrm{~h}$ at $37^{\circ} \mathrm{C}$ at 2-min time intervals in a fluorescence microplate reader (Packard Instrument Co.) using a filter with an excitation wavelength of $360 \mathrm{~nm}$ and a filter with an emission wavelength of $460 \mathrm{~nm}[57,58]$. Data are expressed as the increase in fluorescence as a function of time ( $\Delta$ fluorescence/min) normalized with that of cells incubated in control medium with $0.1 \%$ DMSO.

\section{Reporter Gene Analysis}

The recombinant plasmid $\mathrm{p}(\mathrm{IL} 6 \mathrm{\kappa B})_{3} 50$ hu.IL6P-luc+ was described previously $[59,60]$. Stable transfection of L929sA cells was performed by the calcium phosphate precipitation procedure according to standard protocols [59]. Luciferase and galactosidase reporter assays were carried out according to the manufacturer's instructions (Promega) and have been described previously [59]. Normalization of luciferase activity was performed by mea- surement of $\beta$-galactosidase levels in a chemiluminescent reporter assay Galacto-Light kit (Tropix, Bedford, MA). Light emission was measured in a luminescence microplate reader (Packard Instrument Co.). Luciferase activity, expressed in arbitrary light units, was corrected for the protein concentration in the sample by normalization to the co-expressed $\beta$-galactosidase levels. $\beta$-Galactosidase protein levels were quantified with a chemiluminescent reporter assay Galacto-Light kit (Tropix).

\section{Western blot analysis}

For the western blot analysis of total cell lysates, cells were washed with ice-cold PBS before lysis in catenine lysis buffer (1\% Triton X-100, 1\% NP-40, $10 \mathrm{mg} / \mathrm{l}$ leupeptine, $10 \mathrm{mg} / \mathrm{l}$ aprotinin, $2 \mathrm{mM}$ PMSF, $10 \mathrm{mM}$ sodium fluoride, $10 \mathrm{mM}$ sodium pyrophosphate, $1 \mathrm{mM}$ sodium vanadate). Protein concentration in lysates was measured using $\mathrm{BCA}^{\mathrm{st}}$ Protein Assay Kit (Thermo Scientific, Rockford, USA) according to the manufacturer instructions. Lysates were stored at $-20^{\circ} \mathrm{C}$ until assayed.

Before analysis, lysates were diluted to reach equal protein concentration in each sample, and SDS sample buffer was added $(0.5 \mathrm{mM}$ Tris- $\mathrm{HCl}, \mathrm{pH} 6.8,40 \%$ glycerol, $9.2 \%$ SDS, $5 \%$ mercaptoethanol, and $0.05 \% \mathrm{w} / \mathrm{v}$ bromophenol blue), one part of buffer for three parts of diluted lysate. To shear DNA and reduce sample viscosity, samples were heated to $95^{\circ} \mathrm{C}$ for $5 \mathrm{~min}$, after which they were immediately cooled on ice and microcentrifuged for $5 \mathrm{~min}$. For the western blot analysis of nuclear extract, the nuclear proteins were suspended in SDS sample buffer at the same concentration. The protein samples were separated by $12 \%$ SDS-PAGE and electrotransferred onto a nitrocellulose membrane. Blots were probed using the appropriate antibodies and the immunoreactive protein was detected using enhanced chemiluminescence reagents on an Odyssey imaging system (LI-COR Biosciences, Lincoln, USA).

\section{Electrophoretic Mobility Shift Assay (EMSA)}

After treatment, cells were washed with ice-cold PBS and pelleted in $1 \mathrm{ml}$ PBS by centrifugation for $10 \mathrm{~min}$ at 2600 rpm $\left(4^{\circ} \mathrm{C}\right)$. Preparation of nuclear extracts has been described previously [60]. For EMSA, equal amounts of protein were incubated for 25 min with an NFkB-specific 32P-labeled oligonucleotide and binding mix as described previously [32]. For supershift assay, antibodies were preincubated to the sample of interest for 10 minutes prior to incubation with radiolabeled probe [61]. Labeling of the oligonucleotides was performed with $\left[\alpha-{ }^{32} \mathrm{P}\right]-\mathrm{dCTP}$ by using Klenow enzyme (Boehringer Mannheim). For EMSA competition assays, 100 fold excess of unlabeled $\mathrm{NF} \kappa \mathrm{B}$ oligonucleotide was added to the binding mix. The $\mathrm{NF} \mathrm{B}$ oligonucleotide comprises the sequence: 5'-AGC- 
TATGTGGGTTTTCCCATGAGC-3', in which the single IL6 promoter-derived NFKB motif is bold and italicized. Samples were loaded on a $6 \%$ polyacrylamide gel run in $0.5 \times$ TBE buffer (pH 8) and complexes formed were analyzed using Phosphor Imager Technology.

\section{RNA isolation and real-time Q-PCR analysis}

Total RNA was extracted with the acid guanidinium thiocyanate-phenol-chloroform method using the Trizol reagent (Invitrogen, Merelbeke, Belgium). Reverse transcription was performed on $500 \mathrm{ng}$ of total RNA in a $30 \mu \mathrm{l}$ total volume. For normalization, cDNA concentrations in each sample were determined prior to quantitative realtime PCR (Q-RT-PCR). The Q-RT-PCR was performed on $5 \mu \mathrm{l}$ of each condition using Invitrogen Sybr green platinum Supermix-UDG on a iCycler apparatus (BioRad, Eke, Belgium). All amplifications were performed in duplicate or triplicate, and data were analyzedanalyzed using Genex software (Bio-Rad, Eke, Belgium). Data were expressed as mRNA expression normalized with that of cells incubated in control medium with 0.1\% DMSO. QPCR primers are summarized in Table 1.

\section{Results}

Siamois polyphenols and the withasteroid withaferin A dose dependently inhibit NFKB-driven reporter gene expression

As anti-cancer properties of various polyphenols have been linked to inhibition of the inflammatory transcription factor $\mathrm{NFKB}$, we first compared potential antiinflammatory properties of the Siamois polyphenols quercetin, kaempferol, eriodictyol, WP283 and the withasteroid withaferin A (Fig. 1A) in NFkB-driven reporter gene assays. First, we performed a dose response experiment on L929sA cells, stably transfected with a TNFinducible $\mathrm{NF} K \mathrm{~B}$-driven reporter gene construct with a minimal IL6 promoter ( $\mathrm{p}(\mathrm{IL} 6 \mathrm{~KB})_{3}-50$ hu.IL6P-luc + ) and a constitutively expressed reporter gene construct (pPGкBGeobpA) controlled by the phosphoglycerokinase promoter [60] for normalization of reporter gene expression. Upon TNF treatment, significant promoter induction can be observed with the NFkB-driven reporter gene construct, which can be reversed with quercetin, kaempferol, eriodictyol, WP283 or withaferin A in a dose-dependent manner. IC50 values for NFKB inhibition for the different Siamois polyphenols vary in the concentration range of 30 to $50 \mu \mathrm{M}$ and $0.5-1 \mu \mathrm{M}$ for withaferin A (Fig. 1B).

Siamois polyphenols and withaferin $A$ inhibit endogenous NFKB target gene transcription in K562 and K562/Adr cells, irrespective of doxorubicin sensitivity

To validate our reporter gene expression results in more specific cancer settings, we further studied Siamois poly-
Table 1: Primers sequences used in the real-time Q-PCR. Note: the abbreviations used in the table: FW indicates forward; REV, reverse.

\begin{tabular}{|c|c|}
\hline IL6 FW & GACAGCCACTCACСTСTTCA \\
\hline IL6 REV & АGTGCСтстTTGстGстTтC \\
\hline IL8 FW & GCTCTCTTGGCAGCCTTCCTGA \\
\hline IL8 REV & АСААТААTTTСTGTGTTGGCGC \\
\hline $\mathrm{A} / \mathrm{BFL}-1 \mathrm{FW}$ & GАTTTСАTATTTTGTTGCGGAGTTC \\
\hline $\mathrm{A} / \mathrm{BFL}-1$ REV & TTTCTGGTCAACAGTATTGCTTCAG \\
\hline MCP 1 FW & АСTСTCGCСTCCAGCATG \\
\hline MCP 1 REV & TTGATTGCATCTGGCTGAGC \\
\hline $\mathrm{A} 20 \mathrm{FW}$ & ССтTGстTTGAGTCAGGCTGT \\
\hline A20 REV & TAAGGAGAAGCACGAAACATCGA \\
\hline CYCLIND1 FW & CGCСССАССССТСCAG \\
\hline CYCLIND1 REV & CCGCCCAGACCCTCAGACT \\
\hline VEGF FW & GССTСССTCAGGGTTTCG \\
\hline VEGF REV & GCGGCAGCGTGGTTTC \\
\hline MDR 1 FW & СTGCTTGATGGCAAAGAAATAAAG \\
\hline MDR1 REV & GGCTGTTGTCTCCATAGGCAAT \\
\hline
\end{tabular}

phenol effects in K562 and K562/Adr cells, which may demonstrate different NFKB activation status related to doxorubicin sensitivity [62]. Since NFKB hyperactivation is involved in chemoresistance, we next evaluated whether different types of NFкB inhibitors may have different effects on endogenous NFKB target genes in K562 and $\mathrm{K} 562 / \mathrm{Adr}$ cells, involved in inflammation, metastasis (IL6, IL8, MCP1, A20), cell cycle (cyclin D1), angiogenesis (VEGF), multidrug resistance (mdr1/P-gp), and apoptosis (A1/Bfl1). Cells were pretreated with Siamois polyphenols or withaferin A for $2 \mathrm{~h}$, either or not following $3 \mathrm{~h}$ treatment of PMA, after which RNA was isolated and mRNA levels of interest were quantified by Q-PCR with specific primers. As illustrated in Fig. 2, NFкB target genes are potently induced by PMA in both cell types. Surprisingly, NFkB target genes are differentially expressed in K562 as compared to K562/Adr cells. More particularly, whereas IL6, IL8, MCP1 and A1/Bfl1 reveal stronger transcription in K562 cells, A20, cyclin D1, VEGF and P-gp, are preferentially expressed in K562/Adr cells. Furthermore, repression of PMA-inducible NFkB target genes can be observed in K562 and K562/Adr cells, irrespective of levels of Mdr1/P-gp expression. Interest- 


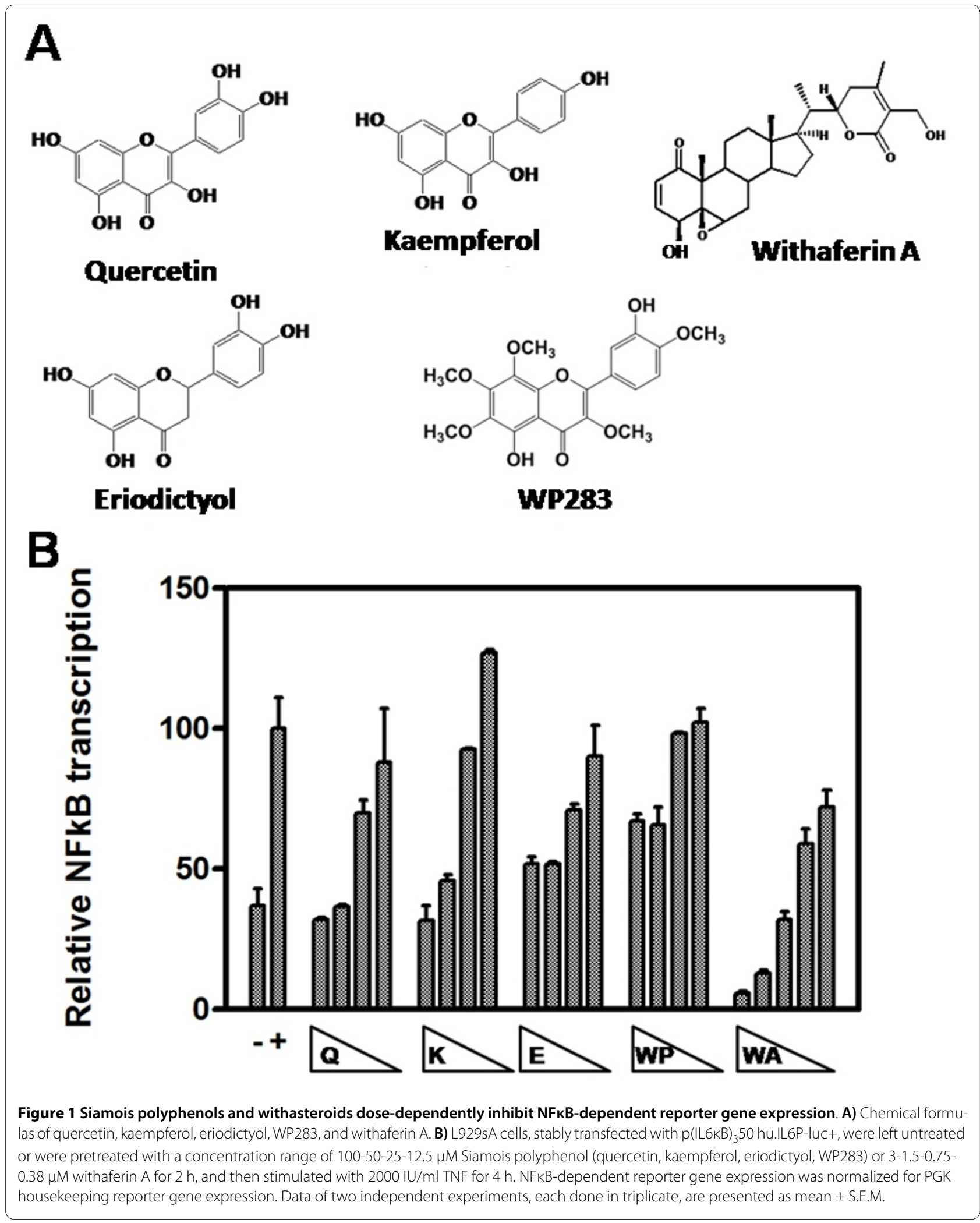

ingly, although NFkB inhibitors can completely reverse the effect of PMA on P-gp expression in K562/Adr cells, its basal transcription levels cannot be further reversed to the background P-gp levels as observed in K562 cells.
Finally, efficacy of target gene repression seems also to be compound- and target gene-specific. Altogether, these results demonstrate differential inhibitory effects of Siamois polyphenols and withasteroids on target genes 

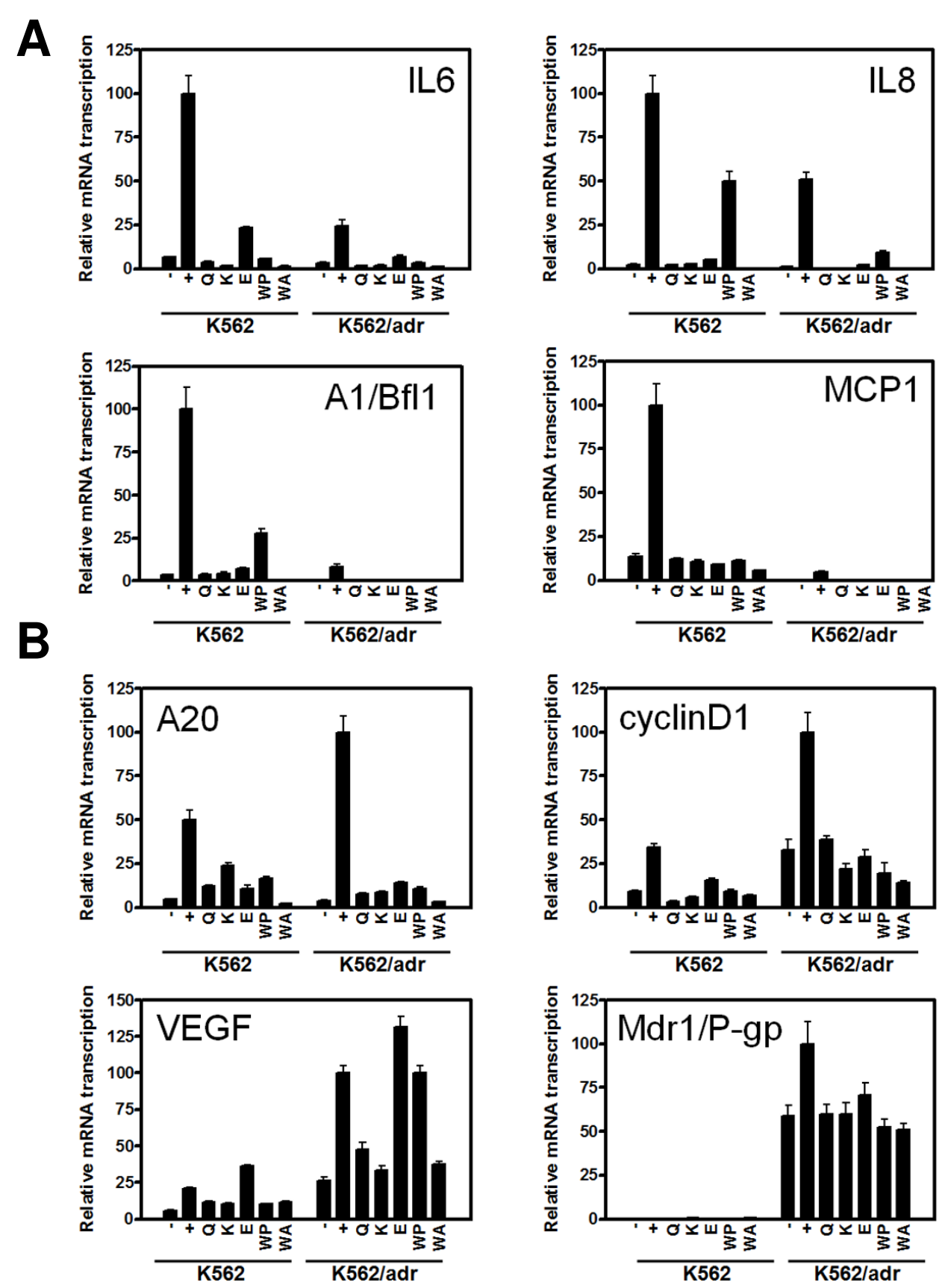

Figure 2 Siamois polyphenols and withasteroids inhibit endogenous NFKB-dependent transcription in K562 and K562/Adr cells. K562 and K562/Adr cells were pretreated with $100 \mu \mathrm{M}$ of quercetin, kaempferol, eriodictyol, WP283, or $6 \mu \mathrm{M}$ of withaferin A for $2 \mathrm{~h}$ followed by incubation with PMA $(0.1 \mu \mathrm{g} / \mathrm{ml})$ for $3 \mathrm{~h}$. Total RNA was isolated and mRNA was converted into CDNA. Relative mRNA levels were quantified by QPCR by specific primer sets for A) IL6, IL8, A1/Bfl1, MCP1, B) A20, cyclin D1, VEGF, mdr1. Specific mRNA transcription levels were normalized by transcription levels of cells incubated in control medium with $0.1 \%$ DMSO. Data of two independent experiments, each done in triplicate, are presented as mean \pm S.E.M. 
involved in inflammation, metastasis, cell cycle, angiogenesis, multidrug resistance, and anti-apoptosis in doxorubicin-sensitive or -resistant $\mathrm{K} 562$ cells.

\section{Siamois polyphenols and withaferin A inhibit endogenous IL6 protein expression in K562 and K562/Adr cells, irrespective of doxorubicin sensitivity}

To evaluate whether inhibition of endogenous NFkB target genes is also translated at the protein level, we performed IL6 ELISA of IL6 protein secreted into the medium of $\mathrm{K} 562$ and K562/Adr cells, pretreated with different doses of quercetin or withaferin A for $3 \mathrm{~h}$, either or not following $15 \mathrm{~h}$ treatment of PMA, after which medium was collected to determine IL6 protein levels. As illustrated in Fig. 3, a comparable dose dependent decrease in IL6 protein levels can be observed in both cell types. In line with the $N_{\kappa} B$ reporter gene results, inhibition of IL6 protein expression can be achieved with lower concentrations withaferin A than quercetin.

\section{All the Siamois polyphenols and withaferin A prevent IKB degradation but the compounds selectively interfere with p38, ERK MAPK, MEK1 and Akt kinase activation}

As NFkB target gene expression encompasses multiple regulatory steps, including $I_{\kappa} B$ degradation, $N F \kappa B$ translocation, $\mathrm{NF}_{\kappa} \mathrm{B} / \mathrm{DNA}$ binding and $\mathrm{NF} \mathrm{KB}$ transactivation, we next aimed to dissect which regulatory steps are affected by Siamois polyphenols in K562 and K562/Adr cells. Since $\mathrm{I} \kappa \mathrm{B} \alpha$ degradation is required for liberation and subsequent translocation of NFKB to the nucleus, we determined Siamois polyphenol effects on PMA-induced $\mathrm{I} \kappa \mathrm{B} \alpha$ protein degradation in $\mathrm{K} 562$ and $\mathrm{K} 562 / \mathrm{Adr}$ cells. As maximal degradation of $I_{\kappa} B \alpha$ is observed between 15-30 minutes after PMA treatment (data not shown), we next measured effects of Siamois polyphenols and withaferin A on IkB degradation following $2 \mathrm{~h}$ pretreatment and 30 minutes cotreatment with PMA. From Fig. 4A, it can be observed that all tested compounds reduce I $\mathrm{B}$ degradation in both cell types. Along the same line, all tested compounds significantly reduce basal and/or PMAinducible p65 Ser536 phosphorylation in both cell types. Altogether, these results suggest that activation of $\mathrm{NF}_{\mathrm{B}} \mathrm{B}$ and subsequent translocation of NFKB for gene induction is significantly reduced in presence of Siamois polyphenols and the withasteroid withaferin A.

As target gene-specific effects are also depending on p65 phosphorylation status and epigenetic settings, dynamically controlled by multiple kinase pathways, i.e. Akt, MAPK, MSK, PKA, we next measured P-Akt, P-p38, $P$-ERK levels in the various experimental conditions in both cell types. A significant reduction of basal and PMA-induced P-Akt and P-p38 levels can be observed upon treatment with quercetin and kaempferol, but not with withaferin A in both K562 cell types (Fig. 4A), whereas P-ERK levels do not reveal significant inhibition (Fig. 4B). In contrast weak ERK stimulation could rather be observed with withaferin A and quercetin (Fig. 4B). Western analysis against p38 and ERK protein levels confirms equal protein loading in the various experimental setups (Fig. 4A). Interestingly, Siamois polyphenols and withaferin A demonstrate increased MEK1-phosphorylation in K562/Adr cells, suggesting that uptake of compounds is not impaired in P-gp-overexpressing K562/Adr cells.

Altogether, besides significant inhibition of IкB degradation and NFkB p65 Ser536 phosphorylation by Siamois polyphenols and withaferin $\mathrm{A}$, compound-specific regulation of p38, ERK, Akt and MEK kinases could be observed, which may further interfere with nuclear transcriptional regulation of NFKB target genes [63-65].

\section{K562 and K562/Adr cells reveal distinct nuclear regulation of NFKB, AP1, Nrf2 and Sirt1 proteins}

As $\mathrm{K} 562$ and K562/Adr demonstrate differential regulation of NFKB target genes, we next explored whether both cell types may show different nuclear regulation of potential cooperative transcription factors (i.e. AP1, Nrf2) or cofactors (Sirt1) which might coregulate NFkB target genes. As can be observed from Fig. 5, basal levels of nuclear NFkB p65, AP1 c-Jun, JunD and Fra1 are significantly increased in K562/Adr cells, but not of cRel and RelB. This confirms previous observations on doxorubicin-resistant MCF7 cells, in which AP1 transcription factors were demonstrated to be responsible for upregulation of P-gp/Mdr1 [66]. Furthermore, PMA treatment significantly increases nuclear levels of $\mathrm{NF}_{\mathrm{K}} \mathrm{B}$ p65, RelB, c-Rel. Of special note, increased nuclear levels of Nrf2 upon PMA treatment are more pronounced in K562/Adr than in K562 cells. Only recently, involvement of Nrf2 has been demonstrated in chemoresistance [67]. Also in line with previous studies on the role of Sirt1 in chemoresistance, basal Sirt1 levels are slightly increased in doxorubicin-resistant K562/Adr cells. More particularly, Sirt1 was found to positively contribute in P-gp/ Mdr1 expression [68]. Altogether, our results demonstrate that activities of NFkB p65, AP1 cjun, junD, Fra1, Nrf2 transcription factors and Sirt1 cofactors are increased in doxorubicin-resistant K562/Adr cells.

NFKB, AP1 DNA-binding profiles in K562 and K562/Adr cells show qualitative and quantitative differences

To compare DNA-binding properties of NFKB and AP1 in K562 and K562/Adr cells, we performed electrophoretic gel shift mobility assays (EMSA) and supershift analysis in response to PMA stimulation. Fig. 6A reveals that both cell types show inducible NFKB/DNA binding, whereas basal NFKB/DNA binding is slightly elevated in doxorubicin-resistant K562/Adr cells, in line with observations 


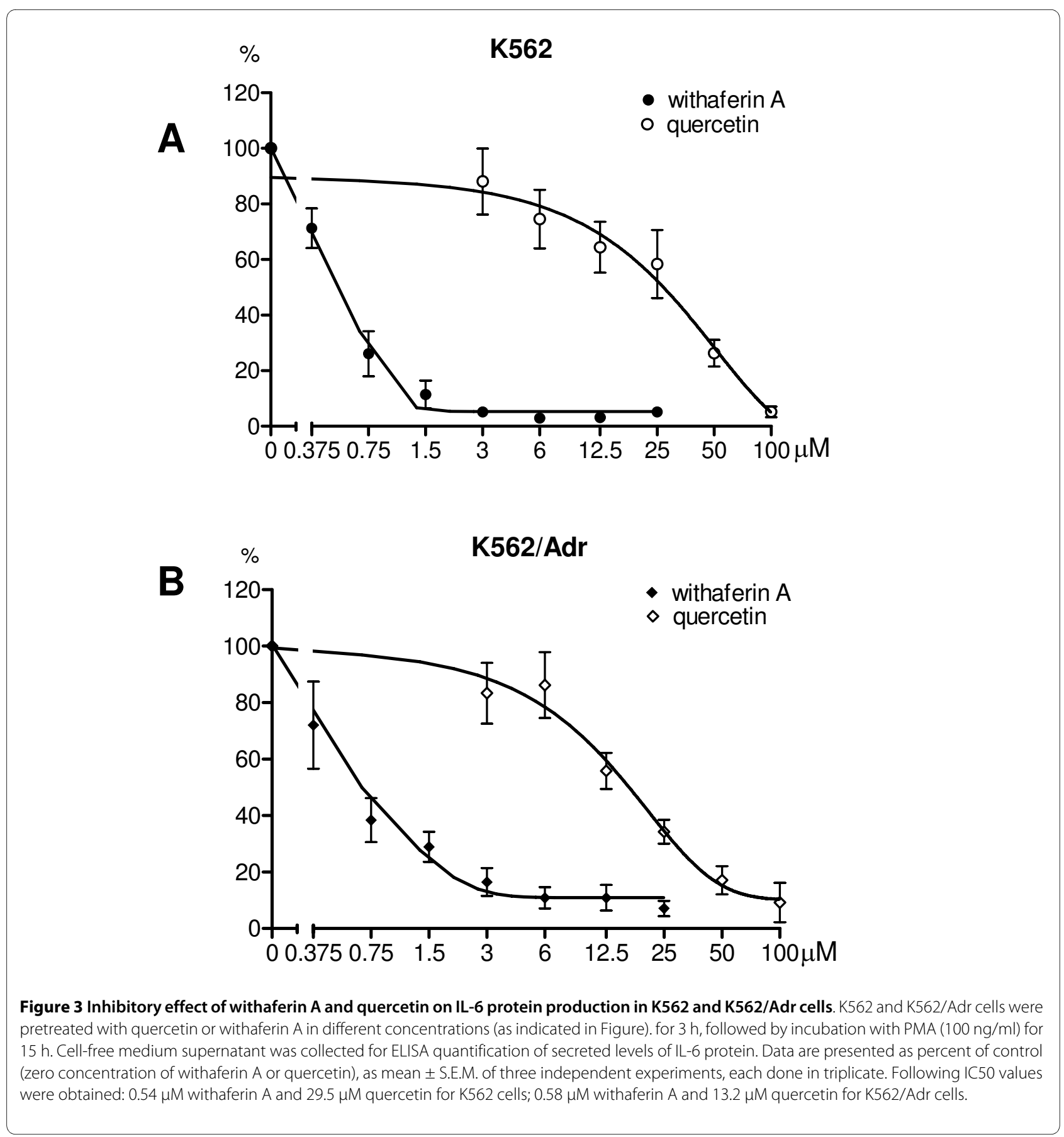

that doxorubicin can elevate basal $\mathrm{NF \kappa B}$ activation via DNA damage pathways [69]. Also, K562 and K562/Adr cells show different composition of NFKB/DNA binding complexes. Interestingly, despite increased levels of NFKB/DNA binding observed in K562/Adr cells, it has been demonstrated that NFKB phosphorylation/acetylation levels are reduced, which affects its transcriptional properties for specific subsets of $\mathrm{NF}_{\mathrm{B}} \mathrm{B}$ target genes $[70,71]$. Along the same line, supershift analysis reveals subtle differences in the heterodimer/homodimer com- position of DNA-bound NFKB and AP1-binding complexes in both cell types. Supershift analysis reveals at least three different $\mathrm{NF} / \mathrm{B} / \mathrm{DNA}$-binding complexes including p65-p65, p50-p65, and p50-p50. In K562/Adr cells, basal NFkB/DNA binding of the p50-p65 complex appears to be increased relative to K562 cells. Similarly, increased basal and inducible AP1 binding is detected in K562/Adr cells in comparison with K562 cells, in line with increased levels of nuclear AP1 members. Furthermore, although both cell types demonstrate PMA induc- 


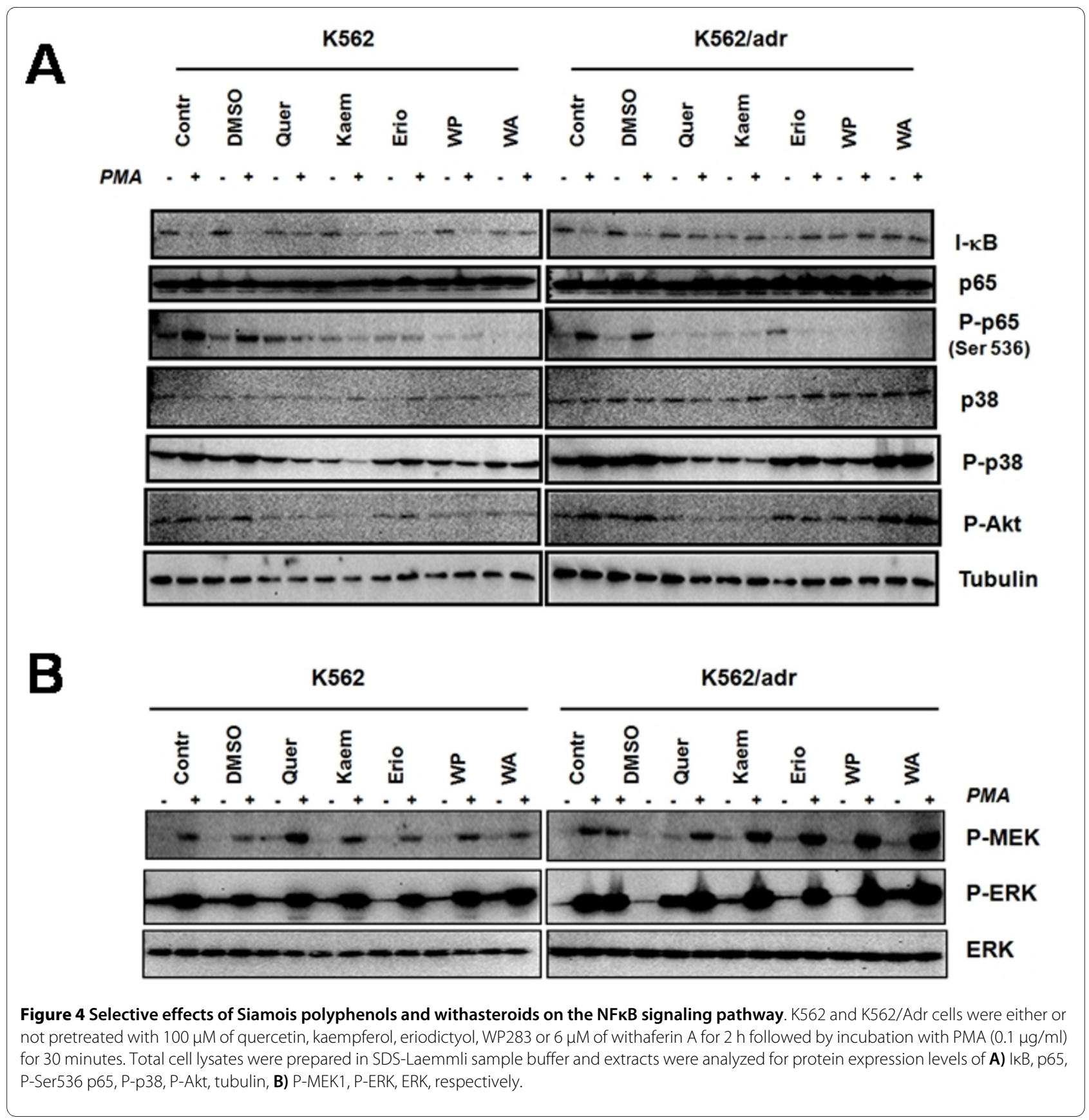

ible NFkB/DNA binding, K562 cells show higher intensity of p65-p65 heterodimers but comparable amounts of p50-p65 and p50-p50 DNA-binding complexes in comparison to K562/Adr cells (Fig. 6A). Concerning AP1-binding complexes, increased Fra1 levels can be detected in K562/Adr cells as compared to K562 cells. EMSA competition with excess of unlabeled NFKB or AP1 DNA-binding motifs further demonstrates specificity of the DNA-bound NFKB, RBP-JK and AP1-binding complexes.
Siamois polyphenols quercetin, eriodictyol and withaferin A strongly inhibit DNA binding of NFKB, AP1 and Nrf2

To verify whether transcriptional repression of target genes involved in inflammation, anti-apoptosis, angiogenesis, metastasis, drug resistance by Siamois polyphenols and withaferin $A$ could be the consequence of inhibition of $\mathrm{NFKB}$, AP1 or Nrf2 TF/DNA binding in K562 and K562/Adr cells, we performed EMSA experiments with nuclear extracts from cells treated with PMA alone, or following pretreatment with Siamois polyphenols. As shown in Fig. 6B, basal constitutive p50-p50 and 


\section{PMA $\frac{\mathrm{K} 562}{-+} \frac{\mathrm{K} 562 / \mathrm{Adr}}{-}$

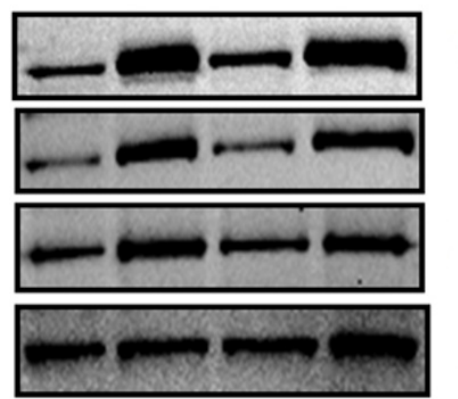 \\ p65 \\ Rel B \\ C-Rel \\ Nrf2

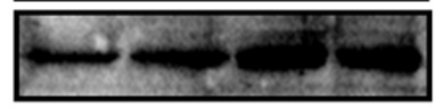 \\ c-Jun

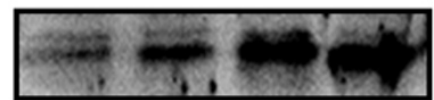 \\ Jun D

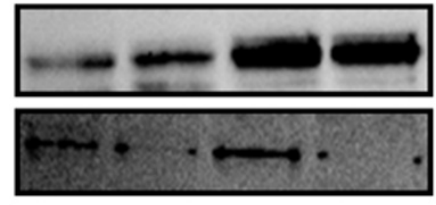 \\ Fra1 \\ Sirt1

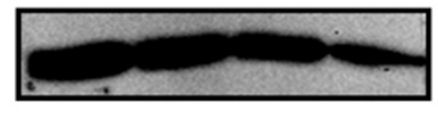 \\ Histone-H3}

Figure 5 K562 and K562/Adr cells reveal different nuclear regulation of NFKB, AP1, Nrf2 transcription factors and Sirt1 cofactors. $\mathrm{K} 562$ and K562/Adr cells were treated with PMA $(0.1 \mathrm{\mu g} / \mathrm{ml})$ for $30 \mathrm{~min}-$ utes. Nuclear cell lysates were prepared in SDS-Laemmli sample buffer and extracts were analyzed for protein expression levels by Western analysis of NFkB p65, RelB, cRel, Nrf2, AP1 cjun, junD, Fra1, Sirt1, respectively. Comparable protein loading was verified with Histone $\mathrm{H} 3$ antibodies.

p50-p65 NFkB/DNA-binding activity in K562/Adr is increased as compared to K562 cells. PMA stimulation again increases p50-p50 and p50-p65 NFkB/DNA binding in both cell types whereas p65-p65 homodimers demonstrate stronger DNA binding in K562 only. Furthermore, treatment with different Siamois polyphenols and withaferin $\mathrm{A}$ causes strong to moderate inhibition of the basal and inducible p50/p65 NFKB/- and AP1/DNAbinding complexes, as shown in Fig. 6B[61]. Along the same line, Nrf2/DNA binding is increased in K562/Adr cells as compared to K562 cells, whereas Siamois polyphenols and withaferin $\mathrm{A}$ are able to reduce basal and PMA-inducible Nrf2 binding in both cell types $[67,72]$. Among the different Siamois polyphenols tested, quercetin and eriodictyol show the strongest inhibition of TF/ DNA binding, whereas kaempferol and WP283 are less effective. Nevertheless, transcriptional inhibition of the various target genes (Fig. 6B) by Siamois polyphenols and withaferin $\mathrm{A}$ is regulated at multiple levels and depends on DNA-binding properties of NFKB, AP1, Nrf2 transcription factors, nuclear cofactor dynamics, as well as epigenetic settings $[64,71,73,74]$. Of special note, although Siamois polyphenols and withaferin A are able to reverse inducible $\mathrm{NF} \kappa \mathrm{B} / \mathrm{DNA}$ binding in K562/Adr cells, constitutive NFKB/DNA-binding levels cannot be further decreased to levels observed in K562 cells.

\section{Siamois polyphenols and withaferin A reduce cell viability in both $\mathrm{K} 562$ and $\mathrm{K} 562 / \mathrm{Adr}$ cells}

K562 and K562/Adr cells which are sensitive or resistant to doxorubicin, respectively, were incubated with doxorubicin, withaferin A or Siamois polyphenols, including quercetin, kaempferol, eriodictyol and WP283 to evaluate cytostatic and/or cytotoxic activity of the various compounds. After $72 \mathrm{~h}$, cell survival was determined by the MTT cell viability assay and the IC50 values are summarized in Fig. 7A. Among Siamois polyphenols, WP283 and eriodictyol exhibit the strongest and weakest effects in mitochondrial reduction of tetrazolium salts to formazan. Of particular interest, K562 and K562/Adr cells reveal comparable sensitivity to Siamois polyphenols and withaferin A, whereas IC50 values for doxorubicin show a 20 -fold higher sensitivity in sensitive K562 cells, as compared to resistant K562/Adr cells. These results indicate a pronounced cellular resistance for doxorubicin as compared to Siamois polyphenols and withaferin A.

To exclude any potential artefacts that may come from interaction of intracellular polyphenols with MTT, which could be directly reduced by these compounds [75], we have also measured cytotoxic effects of quercetin, withaferin A and doxorubicin with a bioluminescent luciferase/ luciferin ATP based cytotoxicity assay (ToxiLight). In accordance with MTT results, K562/Adr cells show cellular resistance to doxorubicin (Fig. 7B). Furthermore, K562 cells show high sensitivity to both withaferin A and quercetin, while K562/Adr cells show significantly reduced sensitivity to quercetin, and their sensitivity to withaferin A is only partially lost in comparison to K562 cells (Fig. 7C).

\section{Withaferin A, but not Siamois polyphenols, induces execution of apoptosis}

Next, K562 and K562/Adr cells were incubated for $48 \mathrm{~h}$ with Siamois polyphenols or withaferin A, followed by annexin V-FITC/PI double staining and FACS analysis to quantify early annexin V-FITC positive) and late (annexin V-FITC/PI double positive) apoptotic cells. The relative percentage of apoptotic/living cells in the different experimental setups in K562 and K562/Adr cells, following 48 $\mathrm{h}$ treatment are represented as a bar graph in Fig. 8. Inter- 


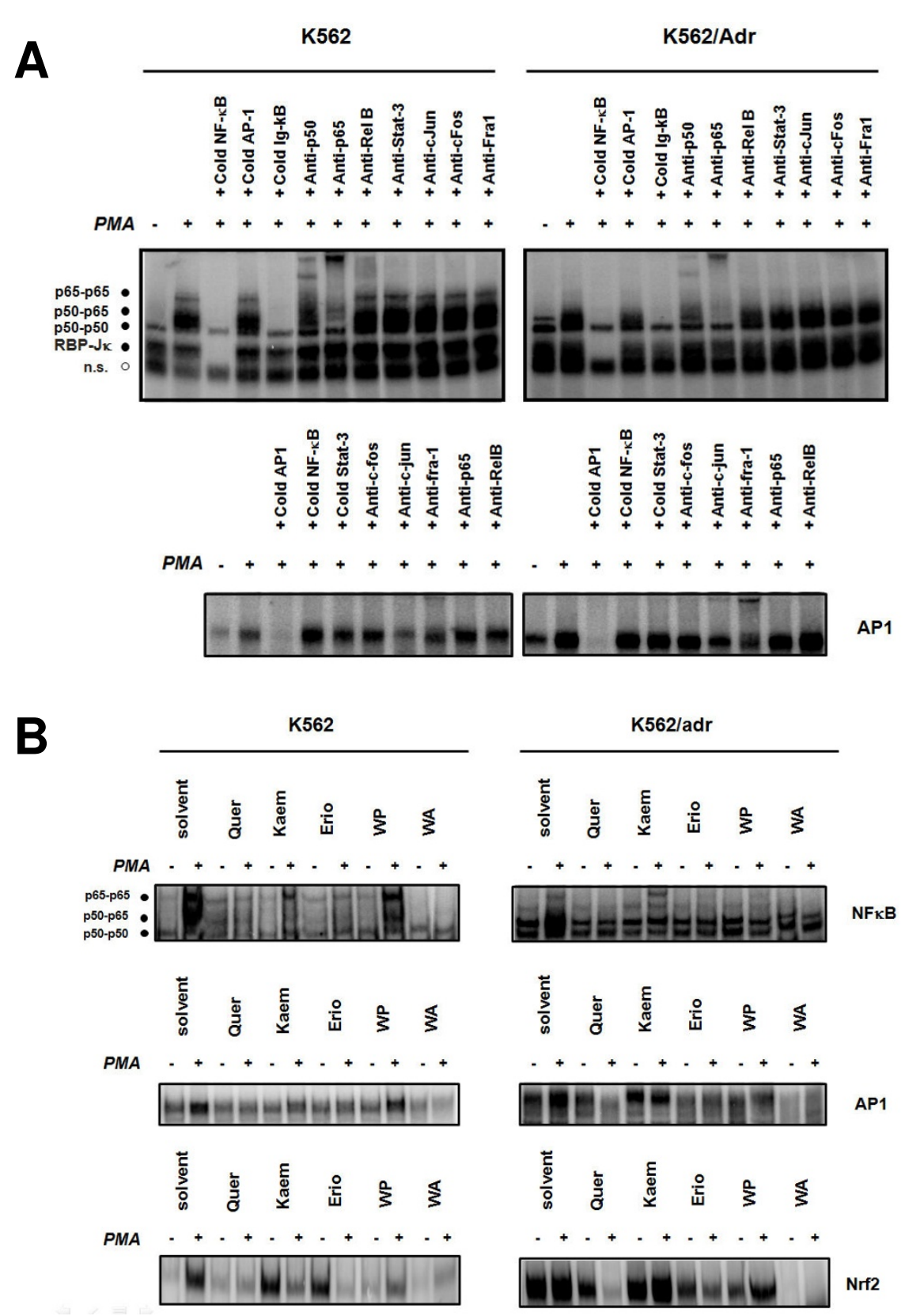

Figure 6 K562 and K562/Adr cells show qualitative and quantitative differences in NFKB and AP1 DNA binding profiles. A) K562 and K562/ Adr cells were pretreated with PMA $(0.1 \mathrm{\mu g} / \mathrm{ml})$ for 30 minutes. Nuclear lysates were analyzed for NFKB/DNA and AP1/DNA binding with a radiolabeled IL6 KB site- or AP1 motif-containing probe. Binding complexes formed were analyzed by EMSA. Loading of equal amounts of protein was verified by comparison with the binding activity of the repressor molecule recombination signal sequence-binding protein $J_{K}$ (RBP-JK). Specificity of the various complexes bound is demonstrated by supershift analysis with NFKB- and AP1-specific antibodies, as well as by competition with 100-fold excess cold oligonucleotide. B) K562 and K562/Adr cells were pretreated with $100 \mu \mathrm{M}$ of quercetin, kaempferol, eriodictyol, WP283, or $6 \mu \mathrm{M}$ of withaferin A for 2 $\mathrm{h}$ followed by incubation with PMA $(0.1 \mathrm{\mu g} / \mathrm{ml})$ for 30 minutes. Cell lysates were fractionated for cytoplasmic and nuclear extracts which were analyzed for NFkB, AP1, or Nrf2-dependent DNA binding with specific radiolabeled probes. Binding complexes formed were analyzed by EMSA.

estingly, although both cell types show comparable early apoptotic cell populations in presence of the different Siamois polyphenols, late apoptotic cells only accumulate in K562 cells. In contrast to Siamois polyphenols, only withaferin A is able to trigger late apoptosis in K562/Adr cells. Furthermore, although the concentrations applied of the different Siamois polyphenols closely relate to the IC50 values determined in MTT assay (Fig. 8), FACS 
A

\begin{tabular}{|c|c|c|}
\hline \multirow{2}{*}{ Compounds } & \multicolumn{2}{|c|}{ IC50 $(\mu \mathrm{M})$} \\
\cline { 2 - 3 } & K562 & K562/adr \\
\hline Quercetin & $26 \pm 2$ & $32 \pm 3$ \\
\hline Kaempferol & $39 \pm 3$ & $60 \pm 4$ \\
\hline Eriodictyol & $>100$ & $>100$ \\
\hline WP283 & $0.03 \pm 0.02$ & $0.03 \pm 0.01$ \\
\hline Withaferin A & $0.2 \pm 0.02$ & $0.2 \pm 0.06$ \\
\hline Doxorubicin & $0.2 \pm 0.04$ & $4.1 \pm 1.0$ \\
\hline
\end{tabular}

B

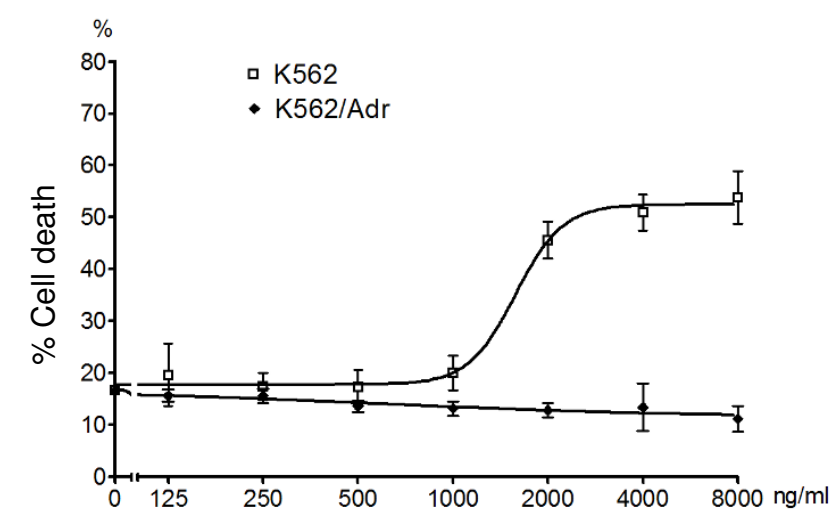

C

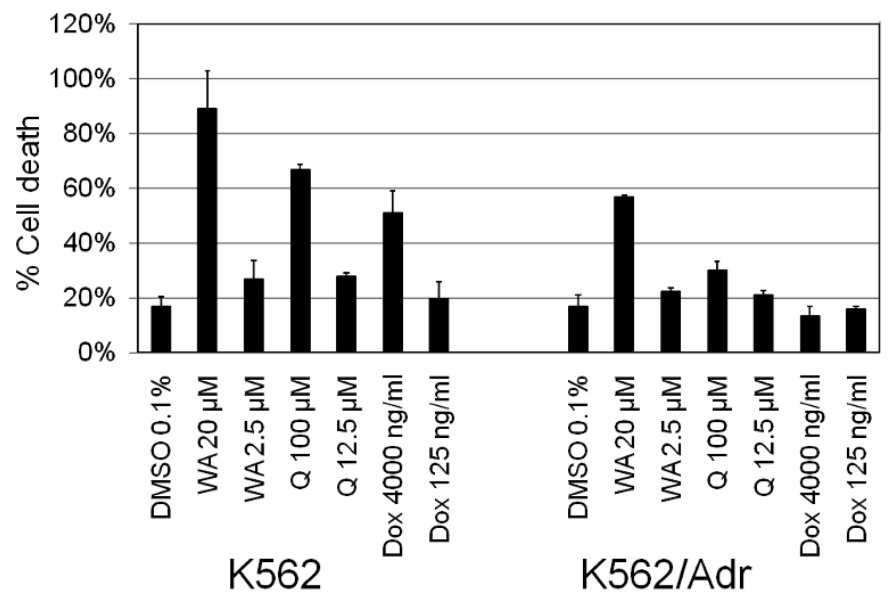

Figure 7 Cytotoxic effects of Siamois polyphenols and withaferin A in K562 and K562/Adr cells. A) K562 and K562/Adr cells were treated with various concentrations of quercetin, kaempferol, eriodictyol, WP283 or withaferin A for $72 \mathrm{~h}$. Cell survival was determined by mitochondrial MTT assay and IC50 values were determined for cytotoxicity of the different compounds. B) K562 and K562/Adr cells were treated with various concentrations doxorubicin for 48 h. \% Cell cytotoxicity was determined by ToxiLight assay. C) K562 and K562/Adr cells were treated with various concentrations withaferin A or quercetin for $48 \mathrm{~h}$. \% Cell cytotoxicity was determined by ToxiLight assay.

analysis (Fig. 8) reveals significant variation in apoptosis efficacy between the different polyphenol compounds. The latter suggests significant discrepancies between MTT cell viability assays revealed by mitochondrial reduction of tetrazolium salts and cell survival score measured by Annexin V/PI apoptosis FACS assay [75]. Indeed, it is of utmost importance to perform multiple, methodologically unrelated assays to quantify dying and dead cells [75,76].

Next, as apoptotic threshold in compound-treated K562/Adr cells may be higher due to elevated basal antiapoptotic activity of $\mathrm{NF \kappa B}, \mathrm{AP1}$ and Nrf2, we wanted to further evaluate whether increasing activity of $N F \kappa B$, AP1 and Nrf2 by PMA treatment in K562 cells could sim- 

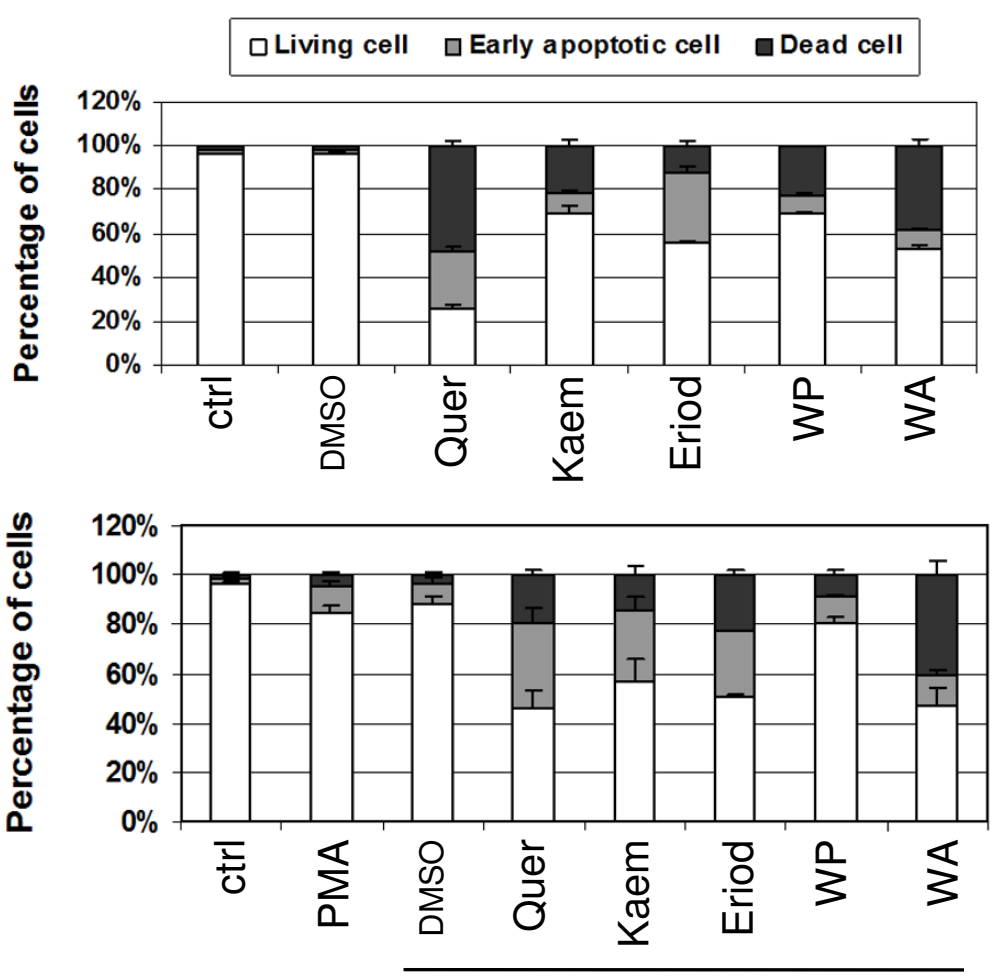

PMA

K562

$+P M A$

K562/adr

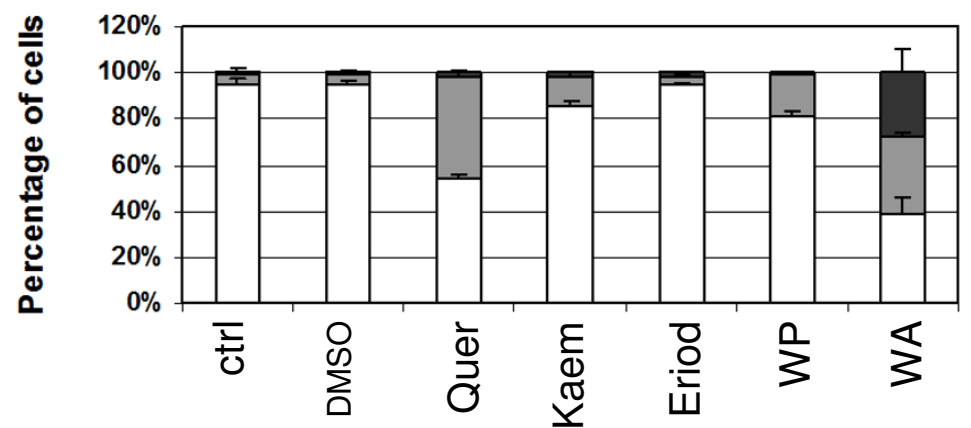

Figure 8 Apoptotic effects of Siamois polyphenols and withasteroids in K562 and K562/Adr cells. Determination of early (AnnexV+, PI-) and late (AnnexV+, PI+) apoptotic cells by flow cytometric evaluation (AnnexinV-FITC and PI staining) of mean normalized percentages of living K562 and K562/Adr cells, either left untreated or treated with $100 \mu \mathrm{M}$ of quercetin, kaempferol, eriodictyol, WP283 or $6 \mu \mathrm{M}$ of withaferin A, or cotreated with PMA $(0.1 \mu \mathrm{g} / \mathrm{ml})$ for $48 \mathrm{~h}$. Data of two independent experiments, each done in duplicate, are presented as mean \pm S.E.M.

ilarly protect compound-treated $\mathrm{K} 562$ cells from late apoptosis in analogy to K562/Adr cells. However, although the relative number of late apoptotic cells decreases upon cotreatment of K562 cells with PMA and Siamois polyphenol inhibitors (Fig. 8), execution of apoptosis is not completely blocked because Siamois polyphenols are able to partially counteract PMA effects on $\mathrm{NF} \kappa \mathrm{B}, \mathrm{AP} 1$ and Nrf2. Along the same line, Siamois polyphenols cannot overcome the late apoptosis block in K562/Adr cells, despite efficient inhibition of $\mathrm{NF}_{\kappa} \mathrm{B}, \mathrm{AP} 1$ and Nrf2. This suggests that execution of apoptosis in $\mathrm{K} 562 / \mathrm{Adr}$ cells is only in part determined by transcrip- tional activity of NFkB, AP1 and Nrf2. Remarkably, although withaferin $\mathrm{A}$, and quercetin both dose dependently inhibit NFkB, AP1 and Nrf2 in K562/Adr cells, only withaferin $\mathrm{A}$ is able to trigger late apoptosis and overcome the apoptosis block in K562/Adr cells, indicating that withaferin A may also affect other death-inducing pathways/mechanisms.

\section{Withaferin A and quercetin induce early and late caspase activation respectively}

In addition to propidium iodide as a late apoptotic FACS marker, we next measured biochemical activation of the 
A

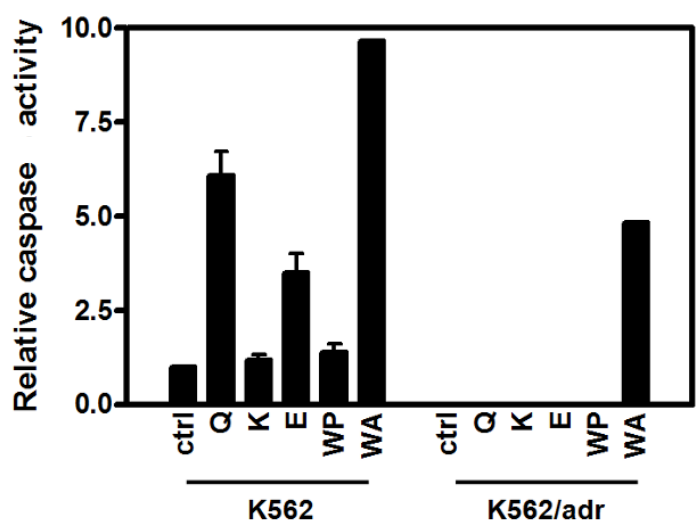

B

K562

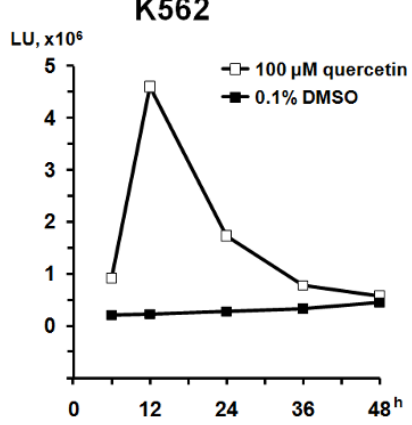

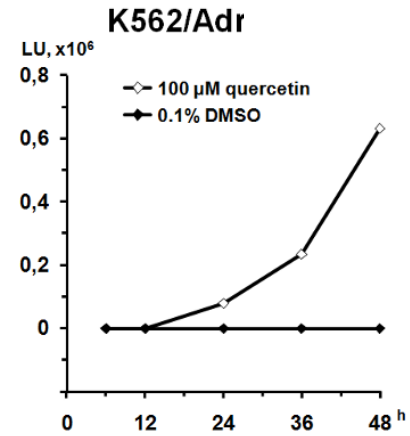

C

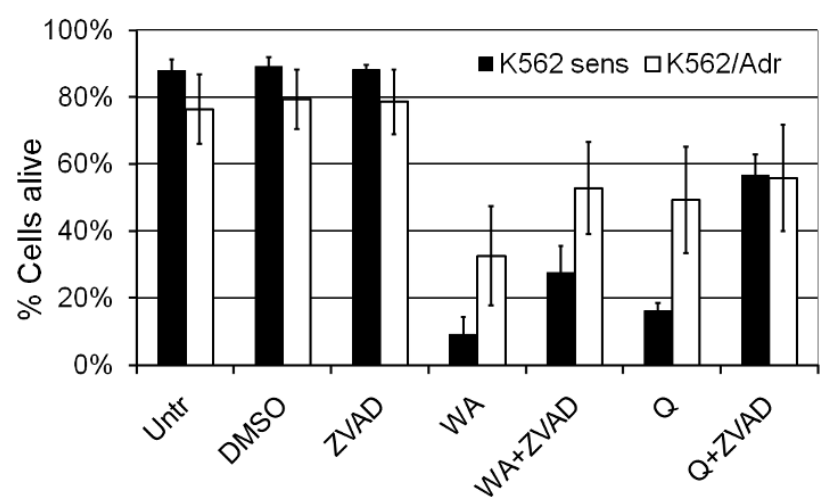

Figure 9 Caspase 3/7 activation by Siamois polyphenols and withaferin A in K562 and K562/Adr cells. A) K562 and K562/Adr cells were either left untreated or treated with $100 \mu \mathrm{M}$ of quercetin (Q), kaempferol (K), eriodictyol (E), WP283 (WP) or $6 \mu \mathrm{M}$ of withaferin A (WA) for 12 h. Caspase-3 activity present in cell lysates was determined by a fluorescent in vitro assay upon incubation of cell lysate with Ac-DEVD-fmk substrate. B) K562 and K562/Adr cells were either left untreated or treated with $100 \mu \mathrm{M}$ quercetin for 6, 12, 24, 36 or $48 \mathrm{~h}$. Caspase-3 activity present in cell lysates was determined by a fluorescent in vitro assay upon incubation of cell lysate with Ac-DEVD-fmk substrate. C) Percentage of living cells, following treatment with withaferin $\mathrm{A}(10 \mu \mathrm{M})$ or quercetin $(100 \mu \mathrm{M})$ in the presence or absence of ZVAD fmk $(50 \mu \mathrm{M})$, inhibitor of caspases. In all conditions, except control, cells were cultivated in medium containing $1 \%$ DMSO. After $48 \mathrm{~h}$ of cultivation, $\%$ dead cells were stained by annexin V/propidiumiodide followed by flow cytometry measurement. \% Living cells is obtained by subtracting \% dead cells. Data of two independent experiments, each done in duplicate, are presented as mean \pm S.E.M.

executioner caspases-3/7 in K562 and K562/Adr cells exposed to PMA, Siamois polyphenols and/or withaferin $\mathrm{A}$ in a fluorescent caspase substrate assay. In this respect, K562 and K562/Adr cells were treated for $12 \mathrm{~h}$ with PMA, Siamois polyphenols and/or withaferin A, after which caspase activity present in the cell lysates was measured in presence of the caspase substrate Ac-DEVD- fmk, which elicits fluorescence upon its cleavage. From Fig. 9A it can be noticed that Siamois polyphenols increase caspase-3/7 activity only in $\mathrm{K} 562$, but not in K562/Adr cells, which is in good accordance with lack of late apoptosis observed in K562/Adr cells. In contrast to Siamois polyphenols, withaferin A is able to trigger caspase-3/7 activity in both cell types Fig. 9A. Interestingly, 
upon evaluation of quercetin-dependent activation of caspase-3/7 at later time points, i.e. $36 \mathrm{~h}$ and $48 \mathrm{~h}$, we observed a delayed but significant increase in caspase-3/7 activity, which could be responsible for attenuation of late apoptosis events in K562/Adr cells exposed to quercetin (Fig. 9B). Kinetic differences in apoptosis by withaferin A and quercetin will be further discussed in paragraphs below. Further support for involvement of caspases in withaferin A- and quercetin-dependent cell death in K562 and K562/Adr cells follows from experiments in presence of the pan-caspase inhibitor ZVAD-fmk. Briefly, K562 and K562/Adr cells were grown for $48 \mathrm{~h}$ in withaferin or quercetin in presence or absence of ZVAD-fmk. As can be observed from Fig. 9C, withaferin A and quercetin both trigger cell death in $\mathrm{K} 562$ cells which can partially be reversed with the pan-caspase inhibitor ZVADfmk. Also in K562/Adr cells, withaferin-dependent apoptosis effects can be partially reversed with ZVAD-fmk, whereas ZVAD-fmk effects on the quercetin-dependent apoptosis setup are much weaker, since quercetin induced caspase-3/7 activation is less efficient or slower than for withaferin treatment.

\section{PARP cleavage by withaferin A in K562 and K562/Adr cells is reversible by thiol donors}

Next, we further investigated by Western analysis whether caspase activation results in cleavage of PARP, caspase substrate and standard marker for apoptosis (Fig. 10). K562 and K562/Adr cells were incubated for $24 \mathrm{~h}$ with different doses of withaferin A or quercetin. In line with our FACS data and toxicity assays, high doses of withaferin A trigger significant PARP cleavage in $\mathrm{K} 562$ cells and to a lesser extent in K562/Adr cells (Fig. 10A). Also quercetin triggers PARP cleavage in K562 cells, although in K562/Adr cells PARP cleavage is strongly impaired or delayed. Since we and others previously demonstrated reversal of biological effects of withaferin in presence of excess amounts of thiol donors (i.e. mercaptoethanol or dithiothreitol (DTT)) $[32,77,78]$, we have further tested whether PARP cleavage by withaferin A could also be prevented in presence of DTT. Interestingly, PARP cleavage by withaferin A in K562 and K562/Adr cells was completely blocked following prior incubation with DTT, illustrating a major role for thioalkylation targets in withaferin A-dependent cytotoxicity (Fig. 10B). In contrast, quercetin effects on PARP cleavage could not be attenuated by DTT in K562 cells.

\section{Effect of withaferin A and quercetin on apoptosis-related proteins in $\mathrm{K} 562$ and $\mathrm{K} 562 /$ Adr cells}

The $\mathrm{Bcl} 2$ family of antiapoptotic proteins $\left(\mathrm{Bcl} 2, \mathrm{Bcl}_{\mathrm{XL}}\right)$, proapoptotic families of $\mathrm{BH} 123$ (Bax) and BH3 (Bim) proteins represent 3 major classes of intracellular regulators of apoptosis. As such, we performed Western analy-
A

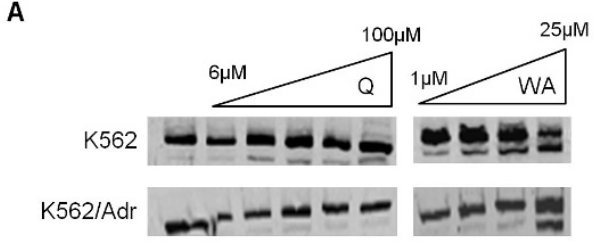

B

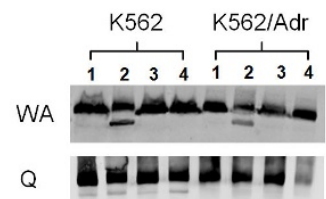

Figure 10 Differential efficacy of PARP cleavage by quercetin and withaferin A in K562 and K562/Adr cells. A) K562 and K562/Adr cells were either left untreated or treated with different doses of quercetin or withaferin A for $24 \mathrm{~h}$. Cell lysates were analyzed for PARP cleavage by Western analysis. B) K562 and K562/Adr cells were either left untreated (1), $24 \mathrm{~h}$ treated with $100 \mu \mathrm{M}$ of quercetin or $10 \mu \mathrm{M}$ withaferin $\mathrm{A}$ (2), $24 \mathrm{~h}$ treated with $100 \mu \mathrm{M}$ quercetin or $10 \mu \mathrm{M}$ withaferin A following $2 \mathrm{~h}$ prior WA preincubation with $1 \mathrm{mM} \mathrm{DTT} \mathrm{(3),} \mathrm{or} 24 \mathrm{~h}$ treatment with $1 \mathrm{mM}$ DTT (4). Corresponding cell lysates were analyzed for PARP cleavage by Western analysis.

sis to evaluate effects of withaferin $A$ and quercetin on $\mathrm{Bcl} 2, \mathrm{Bcl}_{\mathrm{XL}}$, Bax and Bim protein levels in $\mathrm{K} 562$ and K562/Adr cells, exposed for different time periods to high or low concentrations of the compounds. In Fig. 11 we demonstrate that in $\mathrm{K} 562$ cells, withaferin A and quercetin time-dependently and dose-dependently decrease the levels of $\mathrm{Bcl} 2$, Bim and $\mathrm{P}$-Bad protein, whereas $\mathrm{Bcl}_{\mathrm{XL}}$ and Bax levels remain largely unaffected in any condition. Similar results were obtained in K562/Adr cells, although decrease of protein levels is generally delayed (starts to appear at $24 \mathrm{~h}$ rather than $9 \mathrm{~h}$ ). Furthermore, withaferin A decreases protein levels of Bad whereas quercetin has no effect. Finally and of special interest, in analogy to various anti-cancer drugs acting on the cytoskeleton and interfering with tubulin dynamics, withaferin A seems to significantly decrease tubulin protein levels, whereas no effect can be observed in presence of quercetin.

\section{Discussion}

Extensive studies indicate that both hyperactivation of NFKB and overexpression of multidrug transporters play important roles in cancer chemoresistance $[7,18,25,27,62,68]$. Since expression of the multidrug transporter P-gp was found to be NFkB-dependent, it is believed that NFкB inhibitors can decrease P-gp expression and restore chemosensitivity [1,14]. However, our studies have shown that the picture is more complicated. Previously, we have already demonstrated apoptosis of MDA-MB435 cells in presence of Siamois polyphenols in a xenograft model in vivo [53]. Furthermore, the NFKB 


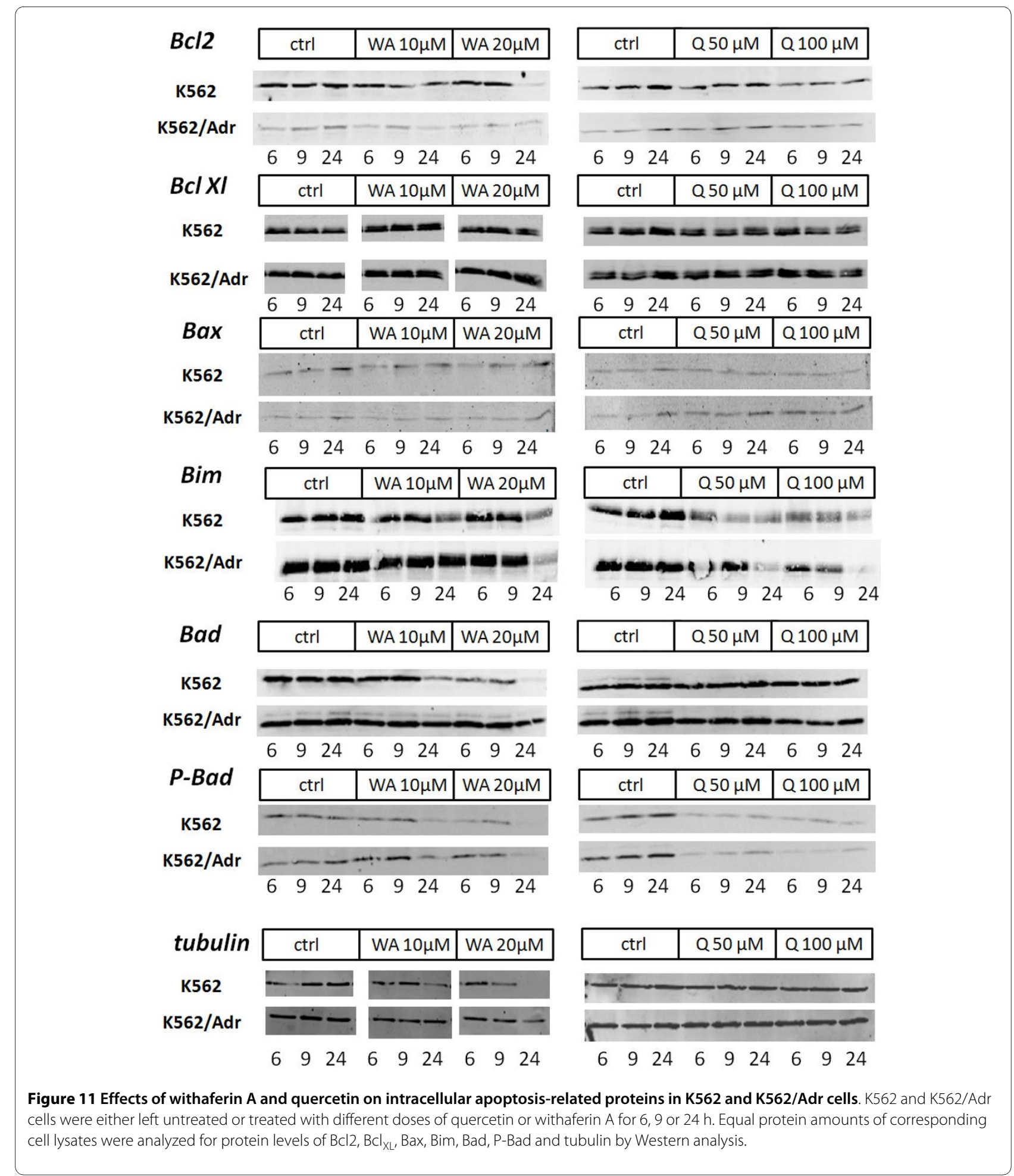

inhibitor withaferin A has been described as a promising drug for cancer chemotherapy and radiosensitization $[32,79,80]$. Now, we further analyzed whether withaferin A or Siamois polyphenols quercetin, kaempferol, eriodictyiol, and WP283 hold therapeutic promise as NFKBinhibitors for chemosensitization of doxorubicin resistant
K562/Adr erythromyelogenous leukemia cells. In NFkB reporter gene studies, we compared dose-dependent repression of luciferase gene expression in response to Siamois polyphenols quercetin, kaempferol, eriodictyiol, and WP283 with IC50 values in the range of 0.1-50 $\mu \mathrm{M}$ respectively. Furthermore, upon comparing endogenous 
gene transcription and protein expression of specific $\mathrm{NF} \kappa \mathrm{B}$ target genes, we observed comparable potencies in NFkB-dependent gene repression by Siamois polyphenols in K562 and K562/Adr cell types. Of special note, both cell types express different subsets of NFKB target genes. More particularly, K562 cells reveal a predominant inflammatory gene expression profile (i.e. strong expression of IL6, IL8, MCP1, and A1/Bfl1), whereas K562/Adr cells demonstrate a more tumorigenic pattern (i.e. strong expression of A20, cyclin D1, VEGF, and mdr1). As such, we further studied NFKB signaling mechanisms and coregulatory pathways which may be responsible for differential NFKB target gene expression/inhibition and apoptosis sensitivity for withaferin A and Siamois polyphenols. Upon characterization of the major NFkB activation and transactivation pathways, we found differential regulation of $\mathrm{NFKB}$ activity by withaferin $\mathrm{A}$ and quercetin, kaempferol, eriodictyol and WP283. Interestingly, I $\kappa B$ degradation and NFkB/DNA binding was significantly reduced by all compounds tested in both cell types, among which withaferin A, quercetin and eriodictyol showing the most potent inhibition, and kaempferol and WP283 much weaker and variable inhibition. Remarkably, increased levels of basal NFkB binding in K562/Adr cells cannot be inhibited by Siamois polyphenols in contrast to inhibition of inducible NFKB/DNAbinding. Furthermore, relative composition of $\mathrm{NF \kappa B} /$ DNA binding complexes reveals that K562 cells contain much higher levels of p65-p65 homodimers. Of particular interest, the inflammatory cytokine IL8 was found to preferentially bind p65-p65 homodimers instead of p50p50 and p50-p65 dimers [81], which could explain strong expression of inflammatory cytokines in K562 cells. From another perspective, NFkB dimer composition may also depend on the repertoire posttranslational modifications present on NFкB $[63,70,71,82,83]$. More specifically, we have detected variable and compound-specific effects on p38 MAPK, MEK1, Akt kinase pathways, which may also interfere with $\mathrm{NF \kappa B}$ transcription factor composition and/or activity. Finally, besides phosphoregulation of transcription factors, acetylation by cofactors (CBP, HDAC, Sirtuin) and DNA methylation have recently added an additional epigenetic control of inducible NFKB transcription [84-87]. Of special note, as doxorubicin was found to increase Sirt1 HDAC levels [68], we compared nuclear Sirt1 levels in both cell types and observed a significant increase in Sirt1 protein in K562/Adr. As such, we cannot exclude that in addition to kinases also Sirt HDACs may contribute in cell-specific phosphoacetylation control of TF/DNA binding and transcriptional activity and may prevent NFkB p65 homodimer formation. In addition to cell specific regulation of $\mathrm{NF}_{\kappa} \mathrm{B}$, it can be observed from Fig. 5 that also AP1 members (i.e. Fra1, cjun and junD) and Nrf2 are differentially expressed in both cell types. As such, we can also neither exclude compound-specific kinase effects on these transcription factor families, since various NFKB target genes involved in inflammation, metastasis, angiogenesis and drug resistance are also coregulated by AP1 and Nrf2 $[66,67,88,89]$.

Most surprisingly, although inhibition of NFKB activity in general contributes in chemosensitization of cancer cells [5,62], caspase activation is delayed and apoptosis is attenuated in K562/Adr cells treated with Siamois polyphenols, although efficacy of NFKB inhibition and initiation of early apoptosis by Siamois polyphenols is similar in doxorubicin-sensitive and resistant cell types. This is in line with previous reports on drug resistance, which describe that P-glycoprotein inhibits cytochrome c release and caspase- $3 / 8$ activation, but not formation of the death-inducing signal complex $[23,24,90]$. Along the same line, impaired activation of caspase 3,6,7,8,9,10 has been described in doxorubicin-resistant breast cancer cells [91]. The fact that Siamois polyphenols are able to completely ablate NFkB target gene expression, hyperactivate MEK1 and trigger early apoptosis in K562/Adr cells argues against the hypothesis that Siamois polyphenols may not be uptaken or are secreted out of the cell because of hyperactivated P-gp activity in K562/Adr cells. As such, P-gp overexpression confers resistance to a wide range of caspase-dependent apoptotic agents not only by removing drugs from the cell, but also by inhibiting the activation of proteases involved in apoptotic signaling [92]. Only a few drugs are reported to overcome this Pgp/Mdr phenotype and most of them are molecules that induce cell death in a caspase-independent manner [93]. Interestingly, in analogy to some specific glutathione $\mathrm{S}$ transferase inhibitors (NBDHEX) and mitochondria-targeting drugs (oligomycin) [94-96], withaferin A was found to bypass the P-gp resistance and to overcome attenuation of late apoptosis in K562/Adr cells. Unfortunately, we could not detect major differences in regulation of intracellular regulators of mitochondrial apoptosis of the $\mathrm{Bcl} 2$, BH123 or $\mathrm{BH} 3$ family proteins in $\mathrm{K} 562$ and K562/Adr cells treated with withaferin A or quercetin: both treatments trigger time-dependent decrease of $\mathrm{Bcl} 2$, Bim and P-Bad protein levels in K562 cells (albeit delayed in $\mathrm{K} 562 / \mathrm{Adr}$ cells). However, upon investigation of cytoskeletal proteins, we observed that withaferin $\mathrm{A}$ is able to decrease tubulin protein levels, whereas $\mathrm{Bcl}_{\mathrm{XL}}$ and Bax protein levels remain unaffected. Interestingly, various chemoresistant tumors, including doxorubicin resistant cancers reveal therapy induced cytoskeletal changes in microtubules and intermediate filaments [97,98]. In analogy to other microtubule-targeted anti-cancer drugs, withaferin A could restore therapy sensitivity in P-gpoverexpressing cells by targeting the cytoskeletal organization. Further support for this mechanism has recently been provided by other groups, describing involvement 
of withaferin A-dependent actin and vimentin microfilament aggregation in cancer cell apoptosis and suppression of angiogenesis via a direct thiol oxidation mechanism $[77,99,100]$. Along the same line, we were able to block withaferin A-induced effects upon competition with excess amounts of the cysteine donor molecule DTT. Alternatively, it cannot be excluded that thiol-reactivity of withaferin A interferes with cysteine-sensitive Pgp protein folding steps and/or P-gp protein function $[101,102]$. Further investigation is needed to map cysteine target proteins of withaferin A which allow to bypass Pgp chemoresistance and restore apoptosis sensitivity.

\section{Conclusions}

We found that transcriptional inhibition of NFkB-, AP1and Nrf2- driven target genes involved in inflammation, metastasis, angiogenesis, drug resistance is not sufficient to overcome the P-gp-coupled attenuation of caspasedependent apoptosis in K562/Adr cells. Remarkably, the withanolide withaferin $\mathrm{A}$ was found to relieve attenuation of caspase activation and apoptosis in K562/Adr cells, presumably via a direct thiol oxidation mechanism which targets cytoskeletal microfilaments, such as tubulin, actin and vimentin. This makes withaferin $\mathrm{A}$ an attractive natural phytochemical compound to overcome drug resistance and to elicit cell death in chemoresistant cell types. However, Siamois polyphenols could also have therapeutical benefit as well, upon suppression of cancer-promoting inflammatory cytokines and growth factors involved in cancer progression [103]. Furthermore, although less effective in immediate eradication of apoptosis-deficient tumor cells, chronic exposure to Siamois polyphenols may demonstrate significant long-term anti-cancer properties upon epigenetic modulation of P-gp function and cell survival $[28,53,104-108]$. The latter strategy may be beneficial to globally retard progression of aggressive refractory tumors, instead of chemotherapy of refractory tumors, which may further select for clonal expansion and evasion of chemoresistant and/or metastatic cancer cells.

\footnotetext{
Abbreviations

NFKB: nuclear factor $\mathrm{kB}$; IKB: inhibitory subunit of NFKB; IKK: IKB kinase; TNF: tumor necrosis factor; IL: interleukin; EMSA: electrophoretic mobility shift assay.
}

\section{Competing interests}

The authors declare that they have no competing interests.

\section{Authors' contributions}

WS carried out the molecular studies and drafted the manuscript. AP, SZ and SG assisted in molecular studies. SM, GH participated in the design of the study. WP has purified WP283. WVB conceived of the study, and participated in its design and coordination and helped to draft the manuscript. All authors read and approved the final manuscript.

\section{Acknowledgements}

W.S. is grateful to the Royal Golden Jubilee Ph.D. Program (Grant No. PHD/ 0286/2545) and the French Embassy in Thailand for their financial support. S.Z. is grateful to the Belgian Science Policy (BELSPO) foundation for the postdoctoral research scholarship. S.G. is a post-doctoral fellow with the F.W.O-Vlaanderen. This work is partially financial supported by the Thailand Research Fund (Grant No. RMU4980034), Interuniversity Attraction Poles (IAP) P6/18, Research grant from F.W.O-Vlaanderen, Research Grant from the Multiple Myeloma Research Foundation, FP7 grant Flaviola and a GOA research grant from Ghent University.

\section{Author Details}

'Laboratory of Physical Chemistry, Molecular and Cellular Biology and Center of Excellence for Molecular Imaging, Department of Radiologic Technology, Faculty of Associated Medical Sciences, Chiang Mai University, Chiang Mai 50200, Thailand, ${ }^{2}$ Laboratory of Natural Products, Department of Chemistry, Faculty of Science, Lampang Rajabhat University, Lampang, Thailand, 'Laboratory of Eukaryotic Gene Expression and Signal Transduction (LEGEST), Department of Physiology, Ghent University, K.L.Ledeganckstraat 35, Gent, Belgium and 4 Lab Protein Science, Proteomics and Epigenetic Signaling, Department of Biomedical Sciences, University Antwerp, Campus Drie Eiken, Universiteitsplein 1, Wilrijk, Belgium

Received: 27 August 2009 Accepted: 3 May 2010 Published: 3 May 2010

\section{References}

1. Nakanishi C, Toi M: Nuclear factor-kappaB inhibitors as sensitizers to anticancer drugs. Nat Rev Cancer 2005, 5:297-309.

2. Hayden MS, Ghosh S: Signaling to NF-kappaB. Genes Dev 2004, 18:2195-2224.

3. Schmitz ML, Mattioli I, Buss H, Kracht M: NF-kappaB: a multifaceted transcription factor regulated at several levels. Chembiochem 2004, 5:1348-1358.

4. Wei H, Saladi R, Lu Y, Wang Y, Palep SR, Moore J, Phelps R, Shyong E, Lebwohl MG: Isoflavone genistein: photoprotection and clinical implications in dermatology. J Nutr 2003, 133:3811S-3819S.

5. Ahmed KM, Li JJ: ATM-NF-kappaB connection as a target for tumor radiosensitization. Curr Cancer Drug Targets 2007, 7:335-342.

6. Gangadharan C, Thoh M, Manna SK: Late phase activation of nuclear transcription factor kappaB by doxorubicin is mediated by interleukin8 and induction of apoptosis via FasL. Breast Cancer Res Treat 2009.

7. Rayet B, Gelinas C: Aberrant rel/nfkb genes and activity in human cancer. Oncogene 1999, 18:6938-6947.

8. Karin M, Greten FR: NF-kappaB: linking inflammation and immunity to cancer development and progression. Nat Rev Immunol 2005, 5:749-759.

9. Baeuerle PA, Baichwal VR: NF-kappa B as a frequent target for immunosuppressive and anti-inflammatory molecules. Adv Immunol 1997, 65:111-137.

10. Duffey DC, Chen Z, Dong G, Ondrey FG, Wolf JS, Brown K, Siebenlist U, Van Waes $C$ : Expression of a dominant-negative mutant inhibitorkappaBalpha of nuclear factor-kappaB in human head and neck squamous cell carcinoma inhibits survival, proinflammatory cytokine expression, and tumor growth in vivo. Cancer Res 1999, 59:3468-3474.

11. Barkett M, Gilmore TD: Control of apoptosis by Rel/NF-kappaB transcription factors. Oncogene 1999, 18:6910-6924

12. Krappmann D, Emmerich F, Kordes U, Scharschmidt E, Dorken B, Scheidereit C: Molecular mechanisms of constitutive NF-kappaB/Re activation in Hodgkin/Reed-Sternberg cells. Oncogene 1999, 18:943-953.

13. Baud V, Karin M: Is NF-kappaB a good target for cancer therapy? Hopes and pitfalls. Nat Rev Drug Discov 2009, 8:33-40.

14. Surh YJ: Cancer chemoprevention with dietary phytochemicals. Nat Rev Cancer 2003, 3:768-780.

15. Aggarwal BB, Vijayalekshmi RV, Sung B: Targeting Inflammatory Pathways for Prevention and Therapy of Cancer: Short-Term Friend, Long-Term Foe. Clinical Cancer Research 2009, 15:425-430.

16. Berghe W Vanden, Dijsselbloem N, Vermeulen L, Ndlovu N, Boone E, Haegeman G: Attenuation of mitogen- and stress-activated protein kinase-1-driven nuclear factor-kappaB gene expression by soy isoflavones does not require estrogenic activity. Cancer Res 2006 $66: 4852-4862$ 
17. Gong L, Li Y, Nedeljkovic-Kurepa A, Sarkar FH: Inactivation of NF-kappaB by genistein is mediated via Akt signaling pathway in breast cancer cells. Oncogene 2003, 22:4702-4709.

18. Gottesman MM, Fojo T, Bates SE: Multidrug resistance in cancer: role of ATP-dependent transporters. Nat Rev Cancer 2002, 2:48-58.

19. Biedler JL: Drug resistance: genotype versus phenotype--thirty-second G. H. A. Clowes Memorial Award Lecture. Cancer Res 1994, 54:666-678.

20. Bosch I, Croop J: P-glycoprotein multidrug resistance and cancer. Biochim Biophys Acta 1996, 1288:F37-54.

21. Goldstein LJ, Galski H, Fojo A, Willingham M, Lai SL, Gazdar A, Pirker R, Green A, Crist W, Brodeur GM, et al:: Expression of a multidrug resistance gene in human cancers. J Natl Cancer Inst 1989, 81:116-124.

22. Johnstone RW: Dual mechanisms of drug resistance by p-glycoprotein inhibition of drug accumulation and caspase activation. In 93rd AACR Annual Meeting San Francisco, CA. Philadelphia: AACR; 2002:28-29.

23. Friedrich K, Wieder T, Von Haefen C, Radetzki S, Janicke R, Schulze-Osthoff K, Dorken B, Daniel PT: Overexpression of caspase-3 restores sensitivity for drug-induced apoptosis in breast cancer cell lines with acquired drug resistance. Oncogene 2001, 20:2749-2760.

24. Ruefli AA, Tainton KM, Darcy PK, Smyth MJ, Johnstone RW: P-glycoprotein inhibits caspase-8 activation but not formation of the death inducing signal complex (disc) following Fas ligation. Cell Death Differ 2002, 9:1266-1272.

25. Bentires-Alj M, Barbu V, Fillet M, Chariot A, Relic B, Jacobs N, Gielen J, Merville MP, Bours V: NF-kappaB transcription factor induces drug resistance through MDR1 expression in cancer cells. Oncogene 2003, 22:90-97.

26. Ros JE, Schuetz JD, Geuken M, Streetz K, Moshage H, Kuipers F, Manns MP, Jansen PL, Trautwein C, Muller M: Induction of Mdr1b expression by tumor necrosis factor-alpha in rat liver cells is independent of $\mathrm{p} 53$ but requires NF-kappaB signaling. Hepatology 2001, 33:1425-1431.

27. Thevenod F, Friedmann JM, Katsen AD, Hauser IA: Up-regulation of multidrug resistance $\mathrm{P}$-glycoprotein via nuclear factor-kappaB activation protects kidney proximal tubule cells from cadmium- and reactive oxygen species-induced apoptosis. J Biol Chem 2000, 275:1887-1896.

28. Kawasaki BT, Hurt EM, Mistree T, Farrar WL: Targeting cancer stem cells with phytochemicals. Mol Interv 2008, 8:174-184.

29. Obolskiy D, Pischel I, Siriwatanametanon N, Heinrich M: Garcinia mangostana L.: a phytochemical and pharmacological review. Phytother Res 2009.

30. Pinto MM, Sousa ME, Nascimento MS: Xanthone derivatives: new insights in biological activities. Curr Med Chem 2005, 12:2517-2538.

31. Bracke ME, Vanhoecke BW, Derycke L, Bolca S, Possemiers S, Heyerick A, Stevens CV, De Keukeleire D, Depypere HT, Verstraete W, et al:: Plant polyphenolics as anti-invasive cancer agents. Anticancer Agents Med Chem 2008, 8:171-185.

32. Kaileh M, Berghe W Vanden, Heyerick A, Horion J, Piette J, Libert C, De Keukeleire D, Essawi T, Haegeman G: Withaferin a strongly elicits IkappaB kinase beta hyperphosphorylation concomitant with potent inhibition of its kinase activity. J Biol Chem 2007, 282:4253-4264.

33. Kunnumakkara AB, Anand P, Aggarwal BB: Curcumin inhibits proliferation, invasion, angiogenesis and metastasis of different cancers through interaction with multiple cell signaling proteins. Cancer Lett 2008, 269:199-225.

34. Paul AT, Gohil VM, Bhutani KK: Modulating TNF-alpha signaling with natural products. Drug Discov Today 2006, 11:725-732.

35. Harborne JB, Williams CA: Advances in flavonoid research since 1992. Phytochemistry 2000, 55:481-504.

36. Jeyabal PV, Syed MB, Venkataraman M, Sambandham JK, Sakthisekaran D: Apigenin inhibits oxidative stress-induced macromolecular damage in $\mathrm{N}$-nitrosodiethylamine (NDEA)-induced hepatocellular carcinogenesis in Wistar albino rats. Mol Carcinog 2005, 44:11-20.

37. Formica JV, Regelson W: Review of the biology of Quercetin and related bioflavonoids. Food Chem Toxicol 1995, 33:1061-1080.

38. Csokay B, Prajda N, Weber G, Olah E: Molecular mechanisms in the antiproliferative action of quercetin. Life Sci 1997, 60:2157-2163.

39. Terra X, Valls J, Vitrac X, Merrillon JM, Arola L, Ardevol A, Blade C, Fernandez-Larrea J, Pujadas G, Salvado J, Blay M: Grape-seed procyanidins act as antiinflammatory agents in endotoxin-stimulated RAW 264.7 macrophages by inhibiting NFkB signaling pathway. J Agric Food Chem 2007, 55:4357-4365.
40. Choi JA, Kim JY, Lee JY, Kang CM, Kwon HJ, Yoo YD, Kim TW, Lee YS, Lee SJ: Induction of cell cycle arrest and apoptosis in human breast cancer cells by quercetin. Int J Oncol 2001, 19:837-844.

41. Patel R, Krishnan R, Ramchandani A, Maru G: Polymeric black tea polyphenols inhibit mouse skin chemical carcinogenesis by decreasing cell proliferation. Cell Prolif 2008, 41:532-553.

42. Kundu JK, Hwang DM, Lee JC, Chang EJ, Shin YK, Fujii H, Sun B, Surh YJ: Inhibitory effects of oligonol on phorbol ester-induced tumor promotion and COX-2 expression in mouse skin: NF-kappaB and C/EBP as potential targets. Cancer Lett 2009, 273:86-97.

43. Dell'Eva R, Ambrosini C, Minghelli S, Noonan DM, Albini A, Ferrari N: The Akt inhibitor deguelin, is an angiopreventive agent also acting on the NF-kappaB pathway. Carcinogenesis 2007, 28:404-413.

44. Matsuda H, Yoshida K, Miyagawa K, Asao Y, Takayama S, Nakashima S, Xu $\mathrm{F}$, Yoshikawa M: Rotenoids and flavonoids with anti-invasion of $\mathrm{HT}$ antiproliferation of U937, and differentiation-inducing activity in $\mathrm{HL}-60$ from Erycibe expansa. Bioorg Med Chem 1080, 15:1539-1546.

45. Geeraerts B, Vanhoecke B, Berghe W Vanden, Philippe J, Offner F, Deforce $D$ : Deguelin inhibits expression of lkappaBalpha protein and induces apoptosis of B-CLL cells in vitro. Leukemia 2007, 21:1610-1618.

46. Beltz LA, Bayer DK, Moss AL, Simet IM: Mechanisms of cancer prevention by green and black tea polyphenols. Anticancer Agents Med Chem 2006, 6:389-406.

47. Lin YL, Tsai SH, Lin-Shiau SY, Ho CT, Lin JK: Theaflavin-3,3'-digallate from black tea blocks the nitric oxide synthase by down-regulating the activation of NF-kappaB in macrophages. Eur J Pharmacol 1999, 367:379-388

48. Hamalainen M, Nieminen R, Vuorela P, Heinonen M, Moilanen E: Antiinflammatory effects of flavonoids: genistein, kaempferol, quercetin, and daidzein inhibit STAT-1 and NF-kappaB activations, whereas flavone, isorhamnetin, naringenin, and pelargonidin inhibit only NFkappaB activation along with their inhibitory effect on iNOS expression and NO production in activated macrophages. Mediators Inflamm 2007, 2007:45673.

49. Dijsselbloem N, Goriely S, Albarani V, Gerlo S, Francoz S, Marine JC, Goldman M, Haegeman G, Berghe W Vanden: A critical role for p53 in the control of NF-kappaB-dependent gene expression in TLR4-stimulated dendritic cells exposed to Genistein. J Immuno/ 2007, 178:5048-5057.

50. Peng Q, Wei Z, Lau BH: Pycnogenol inhibits tumor necrosis factor-alphainduced nuclear factor kappa B activation and adhesion molecule expression in human vascular endothelial cells. Cell Mol Life Sci 2000, 57:834-841.

51. Oak MH, Bedoui JE, Madeira SV, Chalupsky K, Schini-Kerth VB: Delphinidin and cyanidin inhibit PDGF(AB)-induced VEGF release in vascular smooth muscle cells by preventing activation of p38 MAPK and JNK. Br J Pharmacol 2006, 149:283-290.

52. Corona G, Deiana M, Incani A, Vauzour D, Dessi MA, Spencer JP: Inhibition of $\mathrm{p} 38 /$ CREB phosphorylation and COX-2 expression by olive oil polyphenols underlies their anti-proliferative effects. Biochem Biophys Res Commun 2007, 362:606-611.

53. Dechsupa S, Kothan S, Vergote J, Leger G, Martineau A, Berangeo S, Kosanlavit R, Moretti JL, Mankhetkorn S: Quercetin, Siamois 1 and Siamois 2 induce apoptosis in human breast cancer MDA-mB-435 cells xenograft in vivo. Cancer Biol Ther 2007, 6:56-61.

54. Tungjai M, Poompimon W, Loetchutinat C, Kothan S, Dechsupa N, Mankhetkorn S: Spectrophotometric Characterization of Behavior and the Predominant Species of Flavonoids in Physiological Buffer: Determination of Solubility, Lipophilicity and Anticancer Efficacy. The Open Drug Delivery Journal 2008, 2:10-19.

55. Reungpatthanaphong P, Dechsupa S, Meesungnoen J, Loetchutinat $C$, Mankhetkorn S: Rhodamine B as a mitochondrial probe for measurement and monitoring of mitochondrial membrane potential in drug-sensitive and -resistant cells. J Biochem Biophys Methods 2003, 57:1-16.

56. Berghe T Vanden, Denecker G, Brouckaert G, Vadimovisch Krysko D, D'Herde K, Vandenabeele P: More than one way to die: methods to determine TNF-induced apoptosis and necrosis. Methods Mol Med 2004, 98:101-126.

57. Denecker G, Vercammen D, Steemans M, Berghe T Vanden, Brouckaert G, Van Loo G, Zhivotovsky B, Fiers W, Grooten J, Declercq W, Vandenabeele P: Death receptor-induced apoptotic and necrotic cell death: differential role of caspases and mitochondria. Cell Death Differ 2001, 8:829-840. 
58. Berghe TVanden, Kalai M, van Loo G, Declercq W, Vandenabeele P: Disruption of HSP90 function reverts tumor necrosis factor-induced necrosis to apoptosis. J Biol Chem 2003, 278:5622-5629.

59. Berghe W Vanden, Plaisance S, Boone E, De Bosscher K, Schmitz ML, Fiers W, Haegeman G: p38 and extracellular signal-regulated kinase mitogen-activated protein kinase pathways are required for nuclear factor-kappaB p65 transactivation mediated by tumor necrosis factor. J Biol Chem 1998, 273:3285-3290.

60. Berghe W Vanden, De Bosscher K, Boone E, Plaisance S, Haegeman G: The nuclear factor-kappaB engages CBP/p300 and histone acetyltransferase activity for transcriptional activation of the interleukin-6 gene promoter. J Biol Chem 1999, 274:32091-32098.

61. Plaisance S, Berghe W Vanden, Boone E, Fiers W, Haegeman G: Recombination signal sequence binding protein Jkappa is constitutively bound to the NF-kappaB site of the interleukin-6 promoter and acts as a negative regulatory factor. Mol Cell Biol 1997, 17:3733-3743.

62. Bednarski BK, Ding X, Coombe K, Baldwin AS, Kim HJ: Active roles for inhibitory kappaB kinases alpha and beta in nuclear factor-kappaBmediated chemoresistance to doxorubicin. Mol Cancer Ther 2008, 7:1827-1835.

63. Viatour P, Merville MP, Bours V, Chariot A: Phosphorylation of NF-kappaB and IkappaB proteins: implications in cancer and inflammation. Trends Biochem Sci 2005, 30:43-52.

64. Natoli G, Saccani S, Bosisio D, Marazzi I: Interactions of NF-kappaB with chromatin: the art of being at the right place at the right time. Nat Immunol 2005, 6:439-445.

65. Cohen P: Targeting protein kinases for the development of antiinflammatory drugs. Curr Opin Cell Biol 2009, 21:317-324.

66. Daschner PJ, Ciolino HP, Plouzek CA, Yeh GC: Increased AP-1 activity in drug resistant human breast cancer MCF-7 cells. Breast Cancer Res Treat 1999, 53:229-240.

67. Wang XJ, Sun Z, Villeneuve NF, Zhang S, Zhao F, Li Y, Chen W, Yi X, Zheng W, Wondrak GT, et al:: Nrf2 enhances resistance of cancer cells to chemotherapeutic drugs, the dark side of Nrf2. Carcinogenesis 2008, 29:1235-1243

68. Chu F, Chou PM, Zheng X, Mirkin BL, Rebbaa A: Control of multidrug resistance gene mdr1 and cancer resistance to chemotherapy by the longevity gene sirt1. Cancer Res 2005, 65:10183-10187.

69. Gangadharan C, Thoh M, Manna SK: Inhibition of constitutive activity of nuclear transcription factor kappaB sensitizes doxorubicin-resistant cells to apoptosis. J Cell Biochem 2009, 107:203-213.

70. Ho WC, Dickson KM, Barker PA: Nuclear factor-kappaB induced by doxorubicin is deficient in phosphorylation and acetylation and represses nuclear factor-kappaB-dependent transcription in cancer cells. Cancer Res 2005, 65:4273-4281

71. Nowak DE, Tian B, Jamaluddin M, Boldogh I, Vergara LA, Choudhary S, Brasier AR: RelA Ser276 phosphorylation is required for activation of a subset of NF-kappaB-dependent genes by recruiting cyclindependent kinase 9/cyclin T1 complexes. Mol Cell Biol 2008, 28:3623-3638

72. Huang HC, Nguyen T, Pickett CB: Regulation of the antioxidant response element by protein kinase C-mediated phosphorylation of NF-E2related factor 2. Proc Natl Acad Sci USA 2000, 97:12475-12480.

73. Berghe W Vanden, Ndlovu MN, Hoya-Arias R, Dijsselbloem N, Gerlo S, Haegeman G: Keeping up NF-kappaB appearances: epigenetic control of immunity or inflammation-triggered epigenetics. Biochem Pharmacol 2006, 72:1114-1131.

74. Dong J, Jimi E, Zhong H, Hayden MS, Ghosh S: Repression of gene expression by unphosphorylated NF-kappaB p65 through epigenetic mechanisms. Genes Dev 2008, 22:1159-1173.

75. Wisman KN, Perkins AA, Jeffers MD, Hagerman AE: Accurate assessment of the bioactivities of redox-active polyphenolics in cell culture. J Agric Food Chem 2008, 56:7831-7837.

76. Galluzzi L, Aaronson SA, Abrams J, Alnemri ES, Andrews DW, Baehrecke EH, Bazan NG, Blagosklonny MV, Blomgren K, Borner C, et al:: Guidelines for the use and interpretation of assays for monitoring cell death in higher eukaryotes. Cell Death Differ 2009.

77. Chen WY, Chang FR, Huang ZY, Chen JH, Wu YC, Wu CC: Tubocapsenolide $A$, a novel withanolide, inhibits proliferation and induces apoptosis in MDA-MB-231 cells by thiol oxidation of heat shock proteins. J Biol Chem 2008, 283:17184-17193.
78. Misra L, Lal P, Chaurasia ND, Sangwan RS, Sinha S, Tuli R: Selective reactivity of 2-mercaptoethanol with 5 beta,6beta-epoxide in steroids from Withania somnifera. Steroids 2008, 73:245-251.

79. Devi PU: Withania somnifera Dunal (Ashwagandha): potential plant source of a promising drug for cancer chemotherapy and radiosensitization. Indian J Exp Biol 1996, 34:927-932.

80. Devi PU, Akagi K, Ostapenko V, Tanaka Y, Sugahara T: Withaferin A: a new radiosensitizer from the Indian medicinal plant Withania somnifera. Int J Radiat Biol 1996, 69:193-197.

81. Kunsch C, Rosen CA: NF-kappa B subunit-specific regulation of the interleukin-8 promoter. Mol Cell Biol 1993, 13:6137-6146.

82. Benayoun BA, Veitia RA: A post-translational modification code for transcription factors: sorting through a sea of signals. Trends Cell Biol 2009, 19:189-197.

83. Jacque $\mathrm{E}$, Tchenio $T$, Piton $\mathrm{G}$, Romeo PH, Baud V: RelA repression of RelB activity induces selective gene activation downstream of TNF receptors. Proc Natl Acad Sci USA 2005, 102:14635-14640

84. Calao M, Burny A, Quivy V, Dekoninck A, Van Lint C: A pervasive role of histone acetyltransferases and deacetylases in an NF-kappaB-signaling code. Trends Biochem Sci 2008, 33:339-349.

85. Natoli G: When sirtuins and NF-kappaB collide. Cell 2009, 136:19-21.

86. Zhong H, May MJ, Jimi E, Ghosh S: The phosphorylation status of nuclear NF-kappa B determines its association with CBP/p300 or HDAC-1. Mol Cell 2002, 9:625-636.

87. Ramirez-Carrozzi VR, Braas D, Bhatt DM, Cheng CS, Hong C, Doty KR, Black JC, Hoffmann A, Carey M, Smale ST: A unifying model for the selective regulation of inducible transcription by $\mathrm{CpG}$ islands and nucleosome remodeling. Cell 2009, 138:114-128

88. Eferl R, Wagner EF: AP-1: a double-edged sword in tumorigenesis. Nat Rev Cancer 2003, 3:859-868.

89. Ndlovu MN, Van Lint C, Van Wesemael K, Callebert P, Chalbos D, Haegeman G, Berghe W Vanden: Hyperactivated NF\{kappa\}B and AP1 transcription factors promote highly accessible chromatin and constitutive transcription across the IL6 gene promoter in metastatic breast cancer cells. Mol Cell Biol 2009 in press. MCB.01657-08v1

90. Smyth MJ, Krasovskis E, Sutton VR, Johnstone RW: The drug efflux protein, P-glycoprotein, additionally protects drug-resistant tumor cells from multiple forms of caspase-dependent apoptosis. Proc Natl Acad SciUSA 1998, 95:7024-7029.

91. Park SJ, Wu CH, Safa AR: A P-glycoprotein- and MRP1-independent doxorubicin-resistant variant of the MCF-7 breast cancer cell line with defects in caspase- $6,-7,-8,-9$ and -10 activation pathways. Anticancer Res 2004, 24:123-131.

92. Johnstone RW, Cretney E, Smyth MJ: P-glycoprotein protects leukemia cells against caspase-dependent, but not caspase-independent, cell death. Blood 1999, 93:1075-1085.

93. Ruefli AA, Smyth MJ, Johnstone RW: HMBA induces activation of a caspase-independent cell death pathway to overcome P-glycoproteinmediated multidrug resistance. Blood 2000, 95:2378-2385.

94. Ascione A, Cianfriglia M, Dupuis ML, Mallano A, Sau A, Pellizzari Tregno F, Pezzola S, Caccuri AM: The glutathione S-transferase inhibitor 6-(7nitro-2,1,3-benzoxadiazol-4-ylthio)hexanol overcomes the MDR1-Pglycoprotein and MRP1-mediated multidrug resistance in acute myeloid leukemia cells. Cancer Chemother Pharmacol 2009, 64:419-424.

95. Turella P, Filomeni G, Dupuis ML, Ciriolo MR, Molinari A, De Maria F Tombesi M, Cianfriglia M, Federici G, Ricci G, Caccuri AM: A strong glutathione S-transferase inhibitor overcomes the P-glycoproteinmediated resistance in tumor cells. 6-(7-Nitro-2,1,3-benzoxadiazol-4ylthio)hexanol (NBDHEX) triggers a caspase-dependent apoptosis in MDR1-expressing leukemia cells. J Bio/ Chem 2006, 281:23725-23732.

96. Li YC, Fung KP, Kwok TT, Lee CY, Suen YK, Kong SK: Mitochondriatargeting drug oligomycin blocked P-glycoprotein activity and triggered apoptosis in doxorubicin-resistant HepG2 cells. Chemotherapy 2004, 50:55-62.

97. Pasquier E, Andre N, Braguer D: Targeting microtubules to inhibit angiogenesis and disrupt tumour vasculature: implications for cancer treatment. Curr Cancer Drug Targets 2007, 7:566-581.

98. Fromes $Y$, Gounon P, Tapiero H, Fellous A: Effects of fluoro-doxorubicin (ME2303) on microtubules: influence of different classes of microtubule-associated proteins. J Protein Chem 1996, 15:561-573.

99. Bargagna-Mohan P, Hamza A, Kim YE, Khuan Abby Ho Y, Mor-Vaknin N, Wendschlag N, Liu J, Evans RM, Markovitz DM, Zhan CG, et al:: The tumor 
inhibitor and antiangiogenic agent withaferin $\mathrm{A}$ targets the intermediate filament protein vimentin. Chem Bio/ 2007, 14:623-634.

100. Falsey RR, Marron MT, Gunaherath GM, Shirahatti N, Mahadevan D, Gunatilaka AA, Whitesell L: Actin microfilament aggregation induced by withaferin A is mediated by annexin II. Nat Chem Biol 2006, 2:33-38.

101. Loo TW, Clarke DM: Determining the dimensions of the drug-binding domain of human P-glycoprotein using thiol cross-linking compounds as molecular rulers. J Biol Chem 2001, 276:36877-36880.

102. Loo TW, Clarke DM: Determining the structure and mechanism of the human multidrug resistance P-glycoprotein using cysteine-scanning mutagenesis and thiol-modification techniques. Biochim Biophys Acto 1999, 1461:315-325.

103. Aggarwal BB: Inflammation, a silent killer in cancer is not so silent! Curr Opin Pharmacol 2009, 9:347-350.

104. Dashwood RH, Myzak MC, Ho E: Dietary HDAC inhibitors: time to rethink weak ligands in cancer chemoprevention? Carcinogenesis 2006, 27:344-349.

105. Huang C, Cao P, Xie Z: Relation of promoter methylation of mdr-1 gene and histone acetylation status with multidrug resistance in MCF-7/Adr cells. Zhong Nan Da Xue Xue Bao Yi Xue Ban 2009, 34:369-374.

106. Sharma S, Lee D, Li B, Quinlan M, Takahashi F, Maheswaran S, McDermott U, Azizian N, Zou L, Fischbach M, et al:: A Chromatin-Mediated Reversible Drug-Tolerant State in Cancer Cell Subpopulations. Cell 2010, 141:69-80.

107. Dejeux E, Ronneberg JA, Solvang H, Bukholm I, Geisler S, Aas T, Gut IG, Borresen-Dale AL, Lonning PE, Kristensen VN, Tost J: DNA methylation profiling in doxorubicin treated primary locally advanced breast tumours identifies novel genes associated with survival and treatment response. Mol Cancer 9:68.

108. Mishra MV, Bisht KS, Sun L, Muldoon-Jacobs K, Awwad R, Kaushal A, Nguyen P, Huang L, Pennington JD, Markovina S, et al.: DNMT1 as a molecular target in a multimodality-resistant phenotype in tumor cells. Mol Cancer Res 2008, 6:243-249.

doi: 10.1186/1476-4598-9-99

Cite this article as: Suttana et al., Differential chemosensitization of P-glycoprotein overexpressing K562/Adr cells by withaferin A and Siamois polyphenols Molecular Cancer 2010, 9:99

\section{Submit your next manuscript to BioMed Central} and take full advantage of:

- Convenient online submission

- Thorough peer review

- No space constraints or color figure charges

- Immediate publication on acceptance

- Inclusion in PubMed, CAS, Scopus and Google Scholar

- Research which is freely available for redistribution

Submit your manuscript at www.biomedcentral.com/submit
C BioMed Central 